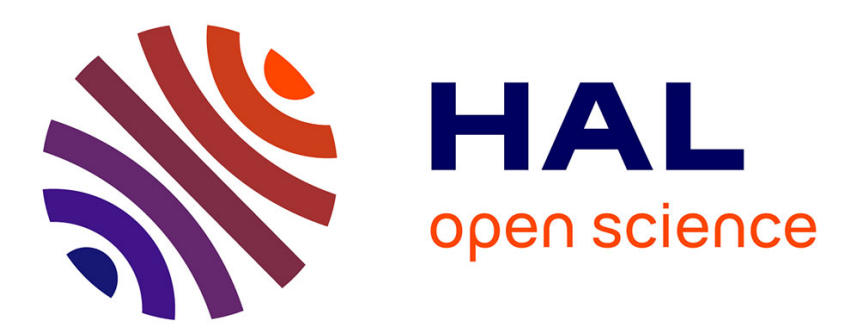

\title{
Crossing-scale hydrological impacts of urbanization and climate variability in the Greater Chicago Area
}

\author{
C. Rougé, X. Cai
}

\section{To cite this version:}

C. Rougé, X. Cai. Crossing-scale hydrological impacts of urbanization and climate variability in the Greater Chicago Area. Journal of Hydrology, 2014, 517, p. 13 - p. 27. 10.1016/j.jhydrol.2014.05.005 . hal-01070493

\section{HAL Id: hal-01070493 \\ https://hal.science/hal-01070493}

Submitted on 1 Oct 2014

HAL is a multi-disciplinary open access archive for the deposit and dissemination of scientific research documents, whether they are published or not. The documents may come from teaching and research institutions in France or abroad, or from public or private research centers.
L'archive ouverte pluridisciplinaire HAL, est destinée au dépôt et à la diffusion de documents scientifiques de niveau recherche, publiés ou non, émanant des établissements d'enseignement et de recherche français ou étrangers, des laboratoires publics ou privés. 


\title{
Crossing-Scale Hydrological Impacts of Urbanization and Climate Variability in the Greater Chicago Area
}

\author{
Charles Rougé ${ }^{1,2}$, Ximing Cai ${ }^{1, *}$
}

8 April 2014

\begin{abstract}
This paper uses past hydrological records in northeastern Illinois to understand the effects of urban development and climatic variability at different spatial scales in the Greater Chicago Area. A step increase in annual precipitation occurred in northeastern Illinois during 1965 - 1972 according to climate records. Urbanization has occurred as a gradual process over the entire Greater Chicago Area, both before and after the abrupt annual precipitation increase. The analysis of streamflow trends at each gaging station is supplemented by the comparison of the evolution of streamflow indicators in a group of urban and agricultural watersheds, thanks to an original use of the MannWhitney test. Results suggest that urban expansion in the Greater Chicago Area has led to widespread increases in a wide variety of streamflow metrics, with the exceptions being spring flows and some of the peak flow indicators. These increases are more homogeneous in large $(>200$ $\left.\mathrm{km}^{2}\right)$ urban watersheds than in small $\left(<100 \mathrm{~km}^{2}\right)$ ones, where local impacts play a bigger role. While the impacts of land-use change are identified across a wide range of flow indicators and spatial scales, there are indications that some of these effects are mitigated or made negligible by other factors. For example, while impervious surfaces are found to increase flooding, stormwater management facilities, an adaptation to increased flooding, mitigate their impacts at a wide range of scales. While impervious surfaces are known to reduce infiltration and baseflow, a low flow increase was triggered by water withdrawals from Lake Michigan, as a response to a rising water demand which made on-site groundwater extraction unsustainable. Our analysis thus highlights the impacts of adaptive planning and management of water resources on urban hydrology.

Keywords: Hydrological change, urbanization, human interferences, climate variability and change, Greater Chicago
\end{abstract}

\footnotetext{
${ }^{1}$ Ven-Te Chow Hydrosystems Laboratory, Department of Civil and Environmental Engineering, University of Illinois at Urbana-Champaign, 205 N. Mathews Avenue, Urbana, IL 61801, United States

${ }^{2}$ Irstea, UR LISC Laboratoire d'ingénierie des systèmes complexes, 9 avenue Blaise Pascal - CS 20085, 63178 Aubière, France
} 


\section{Introduction}

With more than half of the world population now living in cities (Grimm et al., 2008), understanding how the growth of a major urban center affects its environmental footprint is crucial to a better management of present and future water resources. Indeed, urban population growth is believed to be one of the major inducers of water stress worldwide by 2025 (Vörösmarty et al., 2000).

The goal of this work is to carry out a statistical analysis of past streamflow records to understand the different impacts of urban development and water resources management across different scales in the greater metropolitan area of a major city, Chicago. Attention will be particularly devoted to observing whether the synthetic effects of land-use changes are in accordance with the observed hydrological results, or if these results show the impacts of water resources development and management practices.

The basic effects of turning natural soils into impervious surfaces have long been documented in the literature. Such land-use change enhances flooding (Hollis, 1975), leads to the depletion of baseflow and low flows through the reduction of infiltration (Ferguson and Suckling, 1990), and increases total discharge through the reduction of evapotranspiration (Dow and DeWalle, 2000). The impacts of urbanization have been explored with simulation models at different spatial scales (e.g. DeWalle et al., 2000; Hejazi and Moglen, 2007, 2008; Hejazi and Markus, 2009; Hurkmans et al., 2009).

Meanwhile, interferences to base flows and low flows can also come from water resource management activities such as stream channel alteration, inter-basin transfers, effluent discharge, and/or groundwater pumping (Barringer et al., 1994; Meyer, 2005; Claessens et al., 2006; Wang and Cai, 2009), which are adaptations to urbanization with either socioeconomic or environmental consequences, or both.

Likewise, detention basins can locally mitigate peak flows (Solo-Gabriele and Perkins, 1997; Yeh and Labadie, 1997) and they can even play a big role in the watershed's response to rainfall events (Smith et al., 2013). In fact, the effects of these human interferences have countered the effects of landuse change and mitigated or offset them in certain situations (e.g. Barringer et al., 1994; Burns et al., 2005). In the existing literature, however, these effects have all been detected at a single spatial scale, and a complete picture of the consequences of the combined effects of the various water management measures associated with urbanization is not clear. Thus, the overall consequences have not been assessed beyond the scale at which they are detected (e.g. Claessens et al., 2006). In general, it has been argued that interactions between human and natural systems should be investigated crossing scales rather than at a single scale (Liu et al., 2007).

Furthermore, this study also needs to consider the impact of climate fluctuations: a complicating factor when studying human interferences (Claessens et al., 2006; McCormick et al., 2009). Increases in precipitation, in particular in the frequency and magnitude of extreme rainfall events, were reported in the Upper Midwest (Karl and Knight, 1998; Groisman et al., 2004; Pryor et al., 2009; Groisman et al., 2012). Such changes can be linked to climate change (Villarini et al., 2013a) and more precisely with increasing temperatures (Villarini et al., 2013c). Extreme rainfall events have been verified in Chicago (Markus et al., 2007; Villarini et al., 2013b). A wetter climate has been reported to affect the low and mean flows of the Eastern United States (Lins and Slack, 1999, 2005), and has accounted for increases in spring and fall precipitation and streamflow in the Upper Midwest (Lettenmaier et al., 1994; Groisman et al., 2001; Small et al., 2006), including Chicago. In fact, the increase in mean 
annual flow in the Eastern United States has been found to be a step change occurring around 1970 (McCabe and Wolock, 2002), while a similar shift in Illinois water resources has also been documented (Smith and Richman, 1993). Thus, the long-term impacts of climatic variability and those of human interferences must be considered together when looking at streamflow records, as these two types of change can cause distinct temporal patterns, either gradual trends or abrupt steps, with different timings. Examples of this can be found in urbanizing watersheds (Villarini et al., 2009b) or in large river basins, such as the Aral Sea (Glantz, 1999).

In this paper, the main features of climate variability are examined first; following that, the urbanization effects are identified by taking into account the effects of climate variability. Consequently, the present study is to proceed in two steps in order to disentangle the impacts of climate from those of urban development. First, it is to establish the existence of a step increase in rainfall and streamflow in the Greater Chicago Area around 1970, as suggested at greater spatial scales. Second, it is to detect any further gradual changes in streamflow and link them to urban development. Separating a gradual change from an abrupt one within the same time series is a challenging task (Xiong and Guo, 2004). This work attempts to overcome this difficulty in two ways. On one hand, it focuses on distinguishing between the streamflow series where only an abrupt change is present from those where urban development would have more gradual impacts, using, among others, a recent methodological development aimed at making this distinction (Rougé et al., 2013). On the other hand, that same development highlights the challenge to make this distinction based on a single time series; therefore, an original application of the Mann-Whitney test (Mann and Whitney, 1947) extends the paired catchment methodology to paired groups of catchments at the scale of the Greater Chicago Area. Using paired catchments is a classical way of drawing conclusions on different land uses in neighbor catchments where climatic conditions are similar (e.g. Lazaro, 1976; Changnon and Demissie, 1996; Yang et al., 2013). In this work we use the non-parametric Mann-Kendall statistic (Mann, 1945; Kendall, 1975) to represent the temporal evolution of a given streamflow indicator in each basin of each group, then use the Mann-Whitney test to assess the homogeneity of that statistic across both groups.

The rest of this paper is organized as follows. Section 2 presents the shift in precipitation, which is directly related to the streamflow change in the Greater Chicago Area. The configuration of drainage basins and land use are presented in the same section along with the streamflow data, while the methodology for the analysis of streamflow is presented in Section 3. The main temporal patterns discovered in streamflow are outlined in Section 4. Following that, Section 5 discusses the attribution of the observed changes to climate variability and urbanization, in terms of the peak, low, mean, and seasonal flows. Finally, Section 6 concludes this study.

\section{Study area: climate and land-use}

\subsection{Evolution of the regional hydroclimate}

Northeastern Illinois (Figure 1) is reasonably wet and characterized by yearlong rainfall (Milly, 1994b; Sankarasubramanian and Vogel, 2003), with both precipitation and evapotranspiration being higher in summer than in winter (Milly, 1994a). Studies on regional changes in the hydrological cycle since the 1970s are summarized in the introduction. Climate data are now used to understand more accurately 
the changes of precipitation and temperature in the Greater Chicago Area, because they are likely to impact streamflow. The data sources include monthly National Climatic Data Center (NCDC) data throughout northeastern Illinois from 1908-2007 and local daily and monthly precipitation data from eight NCDC rain gages with long and relatively uninterrupted records (Table 1 and Figure 1). Besides rainfall data, temperature data are also used to examine whether there is a relation between the changes in temperature and rainfall (Lettenmaier et al., 1994; Groisman et al., 2004, 2012; Villarini et al., 2013a), or streamflow (e.g. Claessens et al., 2006).

Application of the Pettitt change-point test (Pettitt, 1979) shows a statistically significant $(\alpha=$ 0.05) step change in precipitation in 1965. Figure 2 uses cumulative deviations from the mean of the first part of the record (Buishand, 1982) to display this shift in annual precipitation, also apparent on Figure 3. The difference between the mean annual precipitation from 1908-1964 and 1965-2007 is 97 millimeters annually over the whole Northeastern Illinois climate division of the NCDC. This shift corresponds to a 12 percent increase in annual precipitation over the whole area. The wettest decades occurred in the 1970s and 1980s (Figure 3), confirming that the observed change is a step increase rather than a gradual trend. Our examination of data from neighboring NCDC divisions also reveals a wetter climate after 1965. However, this step increase in precipitation is not linked to rising temperatures. In reality, it is associated with complex seasonal fluctuations at the decadal time scale (Figure 3), consistent with recent findings from Ryberg et al. (2014) in the North Central United States. For instance, the two wettest decades, $1968-1977$ and $1978-1987$, are the respective consequence of decade-long maxima for spring and for summer and fall precipitation. Note that the four seasons are defined within the present work as three-month periods during a calendar year.

At the local level, the analysis for the eight rainfall gages demonstrates that there has been a wetter climate after 1965 than before, with an increase of $70 \mathrm{~mm}$ annually. It also shows significant spatial correlation of precipitation throughout the study area. However, strong local discrepancies exist. For instance, although six out of eight gages display a uniform temporal shift in the mean, the two other ones (Joliet in the south part of the area and Waukegan in the north) display rainfall levels during the late 1980s and early 1990s that are comparable to those of the period before 1965. The Waukegan gage is also the one at which the cumulative rainfall deviations of Figure 2 are substantially different from other gages. This is because precipitation there is less than the regional average by around 40 $\mathrm{mm}$ annually before 1965 , and by $60 \mathrm{~mm}$ annually after 1965 . The Waukegan gage also displays a statistically significant decreasing trend in summer rainfall from 1977 onwards (Figure 4).

\subsection{Land use}

The study area comprises the whole Chicago metropolitan area as well as a few basins predominantly consisting of agricultural land-uses surrounding it to the west and south (See Figure 1 for a map of the area based on the 2001 NCDC land-cover database). This study covers 36 watershed outlets, 26 of which can be classified as urban, while the other 10, situated outside of the Greater Chicago Area, are considered as predominantly rural. Thus, watersheds have been gathered into three groups: Group I stands for the predominantly rural ones, Group II the large (over $200 \mathrm{~km}^{2}$ ) urban watersheds, and Group III the small (under $100 \mathrm{~km}^{2}$ ) urban watersheds (Table 3 ).

Supporting more than ten million inhabitants according to the 2010 Census, (eight million in the 
2000 Census), the Chicago metropolitan area has greatly expanded since the 1960s (Table 2), across several distinct watersheds and at the expense of the surrounding agricultural plains. Growth rates for 1960-2000 depict the speed of this suburban expansion across several counties. The impact of the outward expansion is analyzed by Hejazi and Markus (2009), who inferred the historical land-use data of a dozen suburban watersheds from aerial photography; this process is, however, too time consuming to be applied at the scale of the Greater Chicago Area. Suburban growth rates are compared to that of Cook County, where the city of Chicago lies, suggesting that the development has progressively extended the suburbs farther away from downtown Chicago. The major urbanized watersheds in the Greater Chicago Area are the Des Plaines River and the DuPage River watersheds, both of which drain from north to south. These watersheds have experienced rapid and large-scale urban development, and the impact on streamflow can be best observed, at gages 05532500 (Des Plaines River at Riverside) and 05540500 (DuPage River at Shorewood), respectively. The urbanization history of the former, which is closer to Lake Michigan, is much longer than that of the latter (Changnon and Demissie, 1996).

The ten rural watersheds selected serve as a means to compare the effects of a similar climate on watersheds that have drastically different land uses. The list includes the agricultural Kankakee and Vermilion River watersheds in the South of Chicago, and the Fox River at the western outskirts of Chicago. Originating in Wisconsin, this primarily rural basin now has a rapidly urbanizing zone downstream of the Chain O'Lakes (McConkey et al., 2004). For this reason, two gages at the outlet of different branches of the Kishwaukee River watershed are also picked further West of Chicago.

\subsection{Data}

Daily streamflow data are available at 29 United States Geological Survey (USGS) streamflow gaging stations for the 1953-2007 period and at 36 stations for 1969-2007. Stations are located at the outlet of the watersheds examined in this study (Table 3, Figure 1). The calendar year is selected as the water year because winter is the period with least incoming precipitation. Records do not go beyond 2008 because some stations have incomplete data for these years. Unfortunately, there are no gaging stations located in small rural watersheds (under $100 \mathrm{~km}^{2}$ ), and streamflow observed in urban watersheds of a similar size could not be compared.

\section{Methodology for streamflow analysis}

Section 3.1 presents the construction of streamflow indicators, which serve as a basis for the analysis of streamflow evolution at different scales; Section 3.2 details how the analysis is conducted for each of the individual watersheds while Section 3.3 presents the detection of different evolutions for the three groups of watersheds defined in Section 2.2.

\subsection{Construction of streamflow indicators}

Streamflow is analyzed over the period 1953-2007 for the 29 gages, where the record is long enough, and over 1969-2007 for all 36 gages. Eighteen annual indicators, to be detailed in the following, are extracted from the daily streamflow records. Flow distribution is studied through its deciles, as well as 
the seven-day minimum and mean annual flows. Peak over threshold (POT) sampling (see e.g. Katz et al., 2002; Svensson et al., 2005; Renard et al., 2006; Villarini et al., 2013b; Yang et al., 2013) is also employed to further understand how the frequency of high flow events evolves with time at different watersheds. This is particularly relevant to the Chicago area where, as a recent study (Villarini et al., 2013b) shows, it can be easier to detect changes in POT indicators than in annual daily maximum flow. Peaks are defined as a maximum on a centered 15-day window and only the peaks with the highest values are selected. For POT1, the number of selected peaks equals the number of years of the study record; for POT2, the number of the selected peaks is twice the number of years, and so on. Then these peaks are sorted out depending on their year of occurrence, and the POT time series count the number of peaks for each year of the record, as described in Svensson et al. (2005). Using POT streamflow statistics besides annual daily maximum is particularly relevant in the Chicago area.

Six indicators, the mean and quartiles of the seasonal flow, are also extracted for each of the four seasons, making a total of 24 seasonal indicators, and 42 streamflow indicators overall at each gage. Interest in seasonal flow comes from the seasonality of precipitation and evapotranspiration, which is a major control over the water balance of a watershed (Milly, 1994a).

\subsection{Statistical analysis for each selected watershed}

The presence of a change in the median of each of the 42 flow statistics is assessed for study periods of 1953-2007 and 1969-2007, respectively, leading to 1,218 and 1,512 time series for the analysis. The influence of scale is explored through separate analyses of streamflow changes at the outlet of individual watersheds, for example, by comparing the results for large and small urban watersheds.

Two non-parametric tests are used: the Mann-Kendall trend test (Mann, 1945; Kendall, 1975) and the Pettitt change-point test (Pettitt, 1979). Both test the null hypothesis of no change in the median. The rejection of this null hypothesis by either test at the five percent significance level is sufficient to conclude that there is a change in the median. However, both tests assume that within the time series, deviations from the median, also called residuals are temporally uncorrelated. They are obtained by retrieving the temporal change from the data as described in detail by Rougé et al. (2013). If the residuals are significantly correlated, then the Pettitt test can no longer be applicable and the change detection only depends on the outcome of a modified version of the Mann-Kendall test that accounts for serial correlation (Hamed and Rao, 1998; Yue et al., 2002; Yue and Wang, 2002).

For the period of 1953-2007, another focusing question is whether change can be explained by climatic variability alone, or other processes play a role too. In this work we assume that the step increase in precipitation is going to be mirrored by a step increase in streamflow, and the rationale behind this assumption is demonstrated in Section 4. Gradual processes such as urbanization will cause further changes in streamflow. By convention, a gradual change is defined as one that occurs either during a long period of time or is composed of two or more distinct, rapid changes. The most straightforward way to prove the existence of gradual changes is to detect a statistically significant

change before or after an alleged step change (Villarini et al., 2009a). Since the record preceding the step increase in precipitation in the region is very short, only the period after the step increase (1969-2007) is tested. From now on, if a time series that exhibits a change after the period of step increase, then it will be recognized to have a gradual change of type $G_{1}$. 
However, it has recently been proved that the method described above could work poorly if the period of record was short (under a hundred years) and if the gradual change signal is not strong compared to the variability of the series (Rougé et al., 2013). The same study stresses the absence in the literature of a test of a null hypothesis of "gradual change" versus an alternative hypothesis of "abrupt change", or vice-versa, and therefore it proposes a method that classifies a change as gradual or abrupt. For a time series of length $n$, the method relies on a scaled parameter $d_{c} / n$ comprised between 0 and 1: a change is classified as a gradual change (labeled as $G_{2}$ from now on) if this parameter is higher than a threshold value $D / n$; else it is classified as abrupt. The higher $D / n$ the more difficult to detect gradual changes and the easier to detect abrupt changes. In this work, we use $D / n=0.3$, as recommended in Rougé et al. (2013), which provides a more thorough discussion on the choice of $\mathrm{D} / \mathrm{n}$. We define an abrupt change, also called step change, as a change that is neither $G_{1}$ or $G_{2}$. In the absence of a statistical test to the statement that a given change in the median "is abrupt", no confidence level can be associated to that statement.

A simple model of changes as differentiated into gradual or abrupt ones has been more preferred than more sophisticated models such as the so-called "smooth-change" model associated with the Lombard test (Lombard, 1987; Quessy et al., 2011). There are two reasons explaining this choice. First, a classification of gradual or abrupt is both more parsimonious and sufficient for this study. Second, the reliability of estimates for the dates at which changes start or end has only been tested for time series in which variability is small compared to the magnitude of the change (Quessy et al., 2011). Thus the existing literature on the Lombard test cannot serve as a basis for distinguishing gradual and abrupt in short and noisy time series.

\subsection{Comparing groups of watersheds : field significance, and a Mann- Whitney test}

Testing of the significance of streamflow change at the outlet of individual watersheds is completed by the testing of field significance for the groupings of watersheds defined in Section 2.2, namely

agricultural (Group I), large and urban (Group II), and small and urban (Group III). Field significance tests the null hypothesis stated as "data from all gages in the group are stationary" (Renard et al., 2008). We use the Benjamini-Hochberg procedure (Benjamini and Hochberg, 1995), since it accounts for positive correlation (Benjamini and Yekutieli, 2001). Positive correlation exists over the study area as a result of the spatial correlation of climate data, which is a classical issue in the testing of field significance in hydroclimatic datasets (e.g. Livezey and Chen, 1983; Douglas et al., 2000; Wilks, 2006; Renard et al., 2008).

However, different field significance results between groupings of agricultural and urban watersheds only prove that some agricultural or urban watersheds exhibit a change. It does not mean that as a group of agricultural and a group of urban watersheds behave differently. Furthermore, a non-detection of field significance in a group can be a Type II error, i.e., the null hypothesis is false but cannot be rejected.

Therefore, the comparison between agricultural and urban watershed groups is also made through a direct test of the null hypothesis that a given streamflow indicator undergoes a similar evolution in two groups of watersheds. It is based on the non-parametric Mann-Whitney test (Mann and Whitney, 
1947), which assesses whether the median value of a variable is the same for two different samples. This variable is the Mann-Kendall statistic $S$ :

$$
S=\sum_{i=1}^{n} \sum_{j=i+1}^{n} \operatorname{sgn}\left(x_{j}-x_{i}\right)
$$

Where the sign function is:

$$
\operatorname{sgn}\left(x_{j}-x_{i}\right)=\left\{\begin{array}{lll}
1 & \text { if } & x_{j}>x_{i} \\
0 & \text { if } & x_{j}=x_{i} \\
-1 & \text { if } & x_{j}<x_{i}
\end{array}\right.
$$

$S$ is an indicator of the evolution of the quantity $x$ through time. Thus, in the Mann-Kendall test, $S$ above a threshold value indicates a statistically significant increase in $x$ while $S$ below an opposite threshold value indicates a statistically significant decrease.

In this section though, we use the statistics $S$ as a basis for the Mann-Whitney test to determine whether $S$ is significantly different among a group of predominantly rural watersheds and among a group of urban watersheds. If $S$ is greater for the group of urban watersheds than for the rural ones for a given indicator, one can infer that there is an increase in that indicator in urban areas compared to rural areas. Assuming year-to-year climatic variations are more or less the same throughout the area of study (this is true for the study case), the different evolutions of the streamflow indicator over space can be traced back to urban development.

To illustrate the rationale of the proposed test, the evolution of the mean flow $x$ in two watersheds is considered. If year $A$ is wetter than a later year $B$ in one watershed, one can expect the same condition for the other watershed if the two watersheds are in close proximity. So, since $x_{B}<x_{A}$, we have $\operatorname{sgn}\left(x_{B}-x_{A}\right)=-1$ for both cases. This reasoning applies to all the years of record, and as a result the values of $S$ of the watersheds will be close. Now if one watershed keeps an agricultural land use throughout the period of record whereas the other undergoes urban development, one can expect enhanced runoff from the urbanizing watershed as a consequence of dwindling evapotranspiration. Then we may have $x_{B}>x_{A}$ for the urbanizing watershed even though year $A$ is wetter than year $B$, and therefore $\operatorname{sgn}\left(x_{B}-x_{A}\right)=1$. This is true for every couple of years $A$ and $B$, so by definition, $S$ may take higher values in the urbanizing watershed. This difference is not statistically significant if one considers only these two watersheds; thus, two groups rather than two individuals are considered in this study.

A two-sided Mann-Whitney test is thus performed with a five percent significance level. This test requires each group to contain at least eight watersheds. Since there are only seven agricultural watersheds for the 1953-2007 period, the Mann-Whitney test is only carried out for the 1969-2007 period. For each of the 42 streamflow indicators, Group I (predominantly rural) is compared to three grouping scenarios of urban watersheds: Group II, Group III, and the Groups II and III taken together.

\section{Results}

The results of the streamflow change analysis are summarized in Tables 4 and 5 and Figure 5 . It should be noted that for each group, Table 4 and the left half of Table 5 give the numbers of watersheds for 
which a change is detected when the change is tested at the outlet of individual watersheds (Section 3.2). The field significance of these results is verified if the number of detected changes is marked by bold characters in the Tables. The absence of field significance does not necessarily mean that the detected changes belong to false discoveries, and it only means that those changes could not be corroborated by field significance testing. Therefore, there is no contradiction between the detection of changes at the level of individual gages and the non-detection of field significance. Instead, they should be viewed as being complementary to each other.

With a few exceptions (mostly for small urban watersheds), the majority of significant shifts found over entire time series are flow increases. This section first describes the results for urban and agricultural watersheds in separate subsections, followed by the differences between groups of urban and agricultural watersheds. Results are put in perspective using the step increase in precipitation found in Section 2.

\subsection{Agricultural watersheds: changes during 1965-1972}

Almost all of the changes displayed in Table 4 are neither $G_{1}$ nor $G_{2}$ according to the notations specified in Section 3.2; in fact, most changes are identified as step increases that occurred during the period between 1965 and 1972. Field significance of the change is detected for most of the annual indicators over 1953-2007. No significant increase is found during 1969-2007 (Table 5), neither at individual gages nor across the whole group of watersheds. Thus this further suggests that any changes in runoff from agricultural areas surrounding Chicago occurred around 1965-1972. The major streamflow changes occurred in winter and fall, while significant changes have also been observed during the spring and summer. Figure 5 shows that the change patterns of the mean annual flow, seven-day minimum flow, and maximum daily flow in agricultural watersheds are coincidental with the step increase in rainfall occurring around the end of the 1960s. This is consistent with studies that were conducted at the regional scale in the North Central United States, indicating that climatic fluctuations are the primary driver of streamflow change in the agricultural areas (Tomer and Schilling, 2009; Ryberg et al., 2014). This then justifies the approach chosen for comparing the evolution of urban and predominantly rural watersheds.

\subsection{Urban watersheds}

The field significance of the changes is identified for all indicators in urban watersheds, except for winter (Group II) and spring (Groups II and III) peak flows (Table 4). Besides, many gradual increases are detected in urban watersheds, especially for the lower flow quantiles of annual flow and of seasonal flows in winter, summer, and fall. There are almost as many $G_{1}$ as $G_{2}$ changes (i.e., gradual changes are identified by both methods) with only a few exceptions. It seems that when the presence of a gradual change is clear, which is the case for many urban time series (e.g. for the Salt Creek gage, see Figure 6), both methods have a similar success rate (Rougé et al., 2013). Thus, we can use $G_{1}$ and $G_{2}$ interchangeably for most flow indicators in the study area.

It should be noted that while there are many gradual urban flow increases, many other increases are steps. For instance, for a few indicators (mostly high flow quantiles, peak flows, and spring flows) 
most of the changes are abrupt and located around those years. The existence of many step increases in mean annual flow at urban gages suggests that the precipitation step increase between 1965 and 1972 played a role in making a statistically significant change in many time series of urban watersheds. Step increases are also observed in higher quantiles of flow and POT indicators, as well as spring flow indicators.

Results for the 1969-2007 period (left half of Table 5) suggest that small urban watersheds (Group III) display more diverse evolutions than the larger ones from Group II. Indeed, most changes are increases in large urban basins, but there are many decreases observed in smaller basins. This is a signal showing that the effects of urbanization are heterogeneous in space at the scale of less than a hundred square kilometers, but that these effects tend to average out at the outlet of larger watersheds. In addition, Figure 5 shows temporal change patterns in streamflow in urban areas are more diverse than those in predominantly rural areas, while it also shows how they are spatially organized.

Both mean annual flow and seven-day minimum flow (shown in Figures 5.a and 5.b, respectively) in urban areas predominantly show a mix of step increases, which occurred during 1965-2007, and of gradual changes - even though there are many more gradual changes in the seven-day minimum flow. Mean annual flow increases are only detected in 6 out of 26 urban watersheds over 1969-2007, and mean seasonal flows follow a similar pattern. The field significance of the detected changes is only established for small urban watersheds (Group III), for mean annual and summer flows. Recall that the increases defined as gradual are those occurring outside of the period 1965-1972, when the step increase of precipitation occurred. Those gradual increases are located in DuPage River Basin, which is encompassed by the fast-growing western and southwestern suburbs of Chicago. Records at gages closer to Lake Michigan and downtown Chicago, which correspond to areas with weaker suburban expansion during the analysis period do not display such gradual changes.

Long-term changes in low flows are found in many Chicago suburbs, and these changes prove positive to field significance testing for annual and seasonal indicators, even for the period of 19692007, for both small and large watersheds. These changes take place at all scales, including the outlet of the main urban hydrologic units, such as the Des Plaines River Basin closer to Lake Michigan and in the DuPage River Basin further west of the lake. This pattern of widespread increases is reflected in many low flow indicators (Tables 4 and 5). Yet, northern suburbs show less remarkable continuous increases in low flows, with even decreases in seven-day minimum flow during 1969-2007. This can be partially traced back to a localized decrease in total summer rainfall in the last 30 years of record (Figure 4). In general, there is a greater diversity of change patterns in newer suburbs at the periphery of the city, be it in northern, southern, or western suburban areas.

The change pattern in peak flows in urban areas is even more diversified (Figure 5.c), yet there is no field significance for the peak flow results in urban watersheds in 1969-2007. This is consistent with recent findings on extreme rainfall that can be highly spatially heterogeneous in urban areas, partially due to the presence of urban heat islands (Yang et al., 2013). There are only a few gradual increases in annual daily maximum, but numerous step changes located beyond the period 1965-1972 are detected. Other gages show no increase in peak flow at all, even during 1965-1972. Since there is no established correlation identified in this work between mean annual precipitation and maximum daily flow, one should not assume an automatic connection between the two. 
We now directly confront the results from agricultural and urban areas, and present the results for the paired groups of catchments (right half of Table 5).

\subsection{Comparison of agricultural and urban watersheds}

Several indicators across both urban and agricultural watersheds demonstrate the presence of step increases between 1965 and 1972 despite very different land-use changes. This finding indicates the climatic contribution to streamflow change over the Greater Chicago Area. However, there are also many gradual changes in urban areas (Table 4) detected in 1969-2007, which cannot be attributed to those step increases. Field significance results are also different, both in Tables 4 and 5. This shows a clear difference between the watersheds from Group I and those from Group II and III. Such comparison of groups of watersheds suggests the existence of distinct phenomena driving change in urban areas.

Therefore, the Mann-Whitney test introduced in Section 3.3 is conducted. Whether we compare agricultural watersheds (I) with large urban watersheds (II), small urban watersheds (III) or both small and large urban ones (II plus III), results show that, in general, there is a statistically significant difference in the evolution of most streamflow indicators. Namely, the statistics $S$ are often found to be higher with urban watersheds than agricultural ones, indicating that, assuming a similar climate across all watersheds, streamflow increases occurred in urban areas but not in rural ones, with only a few exceptions (Table 5).

When comparing Group I to all urban watersheds, the only indicators with which no significant increase due to urban development is detected are with the annual daily minimum flow, POT 1, 2 and 5 , and spring flows (excluding the mean). When one compares agricultural watersheds to Group II alone, results are almost the same, except the consequences of urban development are detected for two more indicators, i.e., the urban annual daily minimum and the $25^{\text {th }}$ percentile of the spring daily flow. Conversely, when Group I is compared to Group III alone, there are more indicators for which the test fails to find a difference between the evolution of urban and rural watersheds. Thus, the impacts of streamflow change are best observed when the scale of the urban watersheds considered increases.

These discrepancies between watersheds from groups II and III are due to larger spatial heterogeneities at the small urban watersheds scale, which gives rise to a higher diversity of evolutions. For a certain number of indicators, this diversity makes it more difficult to detect a statistically significant difference when compared to agricultural watersheds. Yet at the scale of larger basins, these differences tend to balance themselves out, which explains why, despite a smaller sample of large urban watersheds, more differences in the evolution of streamflow due to urbanization are detected. The possible causes of these differences are to be discussed further in the following section.

\section{Discussion: influence of urban development on streamflow}

The discussion is organized around the evolutions of four main indicators: annual low flows, annual mean and median flows, annual peak flows, and seasonal flows, with a particular attention to spring flows. 


\subsection{Low flows}

In urban areas, results show a number of gradual increases in seven-day minimum flows as well as lower flow quantiles. The field significance of the results shows their robustness. On one hand, these observation are opposite to what land-use change alone would cause, since the increase in impervious areas is known to lead to a decrease in infiltration, eventually leading to lower baseflow and low flows. On the other hand, the step increase in precipitation cannot account for the many observed gradual increases. Based on the result of low flows, we argue that the effect on low flows is related to water transfers from Lake Michigan to the Greater Chicago Area.

Indeed, most of the surface water withdrawal comes from Lake Michigan (e.g. Wang and Cai, 2009). In fact, most water consumed in Cook and DuPage Counties as well as in the eastern half of Lake County is withdrawn from Lake Michigan (Dziegielewski and Chowdhury, 2012). This is also the case for some parts of Will County, which are located in the lower DuPage River and Hickory Creek Watersheds. Most gradual increases in low flows concern watersheds located in those areas. The switch from local groundwater to Lake Michigan water took place after new wastewater treatment facilities were opened in western, southwestern, and northern suburbs (Singh and Ramamurthy, 1993) in the 1970s, posterior to the rainfall increase of 1965 .

Thus, gradual low flow increases are due to a hydrological impact of urban development that is not directly related to the change of land cover. Indeed, they result from a side-effect of the response to a large-scale water resources challenge, which is the need to find a sustainable source of water for a major urban area. Water withdrawals from Lake Michigan arguably are an adaptive response to this challenge. Increased low flows are apparent through the evolution of seven-day minimum flows in many watersheds (Figure 7), and these increases often coincide with the onset of water withdrawals in the 1970s. This is the case, for instance, at the outlets of the two largest urban watersheds, the Des Plaines and DuPage River Basins (Figures 7.a and 7.b, respectively). In the former, withdrawals from Lake Michigan started in an already largely urbanized watershed at the end of the 1970s, and caused a step increase in 7-day minima due to effluent discharge. In the latter, however, population kept increasing during the whole period of record (Table 2; Villarini et al., 2013b), and so did the 7-day minimum flows. Similarly, Wang and Cai (2009) examined the low flow recession at the outlet of another large urban watershed, the Salt Creek watershed (Figure 6) near the suburbs west of Chicago. There, effluent discharge led to low flow increases as soon as water was withdrawn from Lake Michigan, replacing water pumped from the local unconfined aquifer. Thus, water withdrawals from Lake Michigan led to low flow increases in large urban watersheds as soon as they started, which is a result of population increase and suburban development in the greater Chicago area.

In fact, the impacts of flow regulation and/or effluent discharge are so widespread that only three of the small urban watersheds investigated in this study have not been affected in the past 50 years (Meyer, 2005). These factors, along with others such as climatic fluctuations and land-use change, have produced a variety of different evolutions of low flow in small urban watersheds. The only statistically significant decreases can be found in the Skokie River watershed located in the northern suburbs (e.g., Figure 7.c). There, land-use change and decreasing summer rainfall over the last 30 years contributed to a decrease in 7-day minima since the 1970s. Much to the contrary, one can observe a gradual increase in low flows in two of the three aforementioned watersheds where effluent discharge and flow regulation 
are absent (e.g., Tinley Creek on Figure 7.d). The causes must be found with factors that help replenish the local aquifers in spite of land-use change, such as leakage from the water distribution system or infiltration from garden irrigation (Grimmond et al., 1986; Grimmond and Oke, 1986). Those factors contribute to the low flow increase through aquifer discharge, which should be further explored by thorough monitoring of the aquifer at the scale of these small watersheds, so as to determine whether water withdrawals from Lake Michigan ultimately lead to an increasing water table.

\subsection{Mean flows}

An increase in precipitation, such as the one that occurred in the study area, primarily influences mean flows. Yet, the step increase in precipitation as described in Section 2.1 can only explain step changes. The fact that precipitation was highest during 1968-1987 (Figure 3)), although it consistently remained above the pre-1965 level during 1965-2007, hinders the detection of gradual changes over 1953-2007, as well as the detection of field significance over 1969-2007. Causes for changes outside the 19651972 period are land-use change and effluent discharge. The former leads to a greater percentage of impervious surfaces, which increases runoff and tends to reduce evapotranspiration and natural infiltration. The latter is due to water withdrawals from external water bodies, and directly increases mean annual discharge (Figure 6). However, Figure 5.a only displays a few gradual changes, an observation which offers a counter-example to the previous finding that the effect of land-use change on evapotranspiration could even offset streamflow depletion due to climatic factors (DeWalle et al., 2000).

Nevertheless, the Mann-Whitney tests on comparative evolutions of groups of watersheds showed that not only the mean annual flow, but also the median and most flow deciles increased in urban areas compared to agricultural ones. This highlights the impact of non-climatic factors such as evapotranspiration and water withdrawals from Lake Michigan. It also stresses the relevance of the method described in Section 3.3 when climatic fluctuations complicate the analysis of the impacts of urban development.

\subsection{Peak flows}

Given that impervious surfaces increase peak discharge when they replace natural soil, the observed increases in urban peak discharge are milder than what is expected, especially since the field significance of the results could not be proved over 1969-2007. In particular, Villarini et al. (2013b) recently found unequivocal impacts of urbanization on peak discharge behavior in the western part of the Greater Chicago Area. Stormwater management facilities explain this paradox, which is apparent at different urban scales.

Infiltration in natural soil is a threshold process (Zehe and Sivapalan, 2009), and so is storage of water by stormwater management facilities. Indeed, flood planning engineers conceive and operate stormwater management facilities by attempting to maintain flood levels under a certain threshold (Yeh and Labadie, 1997), except for the most extreme ones. They replace natural infiltration, since in both cases water is retained, either by the reservoir or by the soil, until their capacity is reached. The construction of those facilities is driven by the ever-increasing costs of flooding (e.g. Katz et al., 
2002), so it can be seen as an adaptive process that takes place at the scale at which floods occur. Such adaptation is most visible in the case of Addison Creek (05532000) for which the construction year and capacity of off-stream reservoirs was available (Erik L. Gil, P.E., personal communication). Results show that the construction of the second-largest reservoir in 1986, after the largest one built in 1977, had the most impact on the frequency of POT 1, 2 and 3 (Figure 8). Success of this adaptive management measure is also apparent from Figure 9, where Addison Creek is associated with gage number 25 .

Furthermore, Figure 9 illustrates that adaptation to rising floods and property exposure in urban watersheds is a local process. There are huge discrepancies between the evolutions of the POT indicators in small urban watersheds. These heterogeneities are reduced at the level of larger watersheds. The only large urban watershed for which significant increases are observed across all POT indicators is the West Branch DuPage River (05540095), which drains relatively new suburbs west of Chicago. In general, increases in peak flow indicators are more visible at the outlet of watersheds that irrigate newer suburbs, such as those Villarini et al. (2013b) studied.

Comparisons between urban and agricultural watersheds show that the only peak flow indicators by which evolution is significantly different in urban watersheds are the annual daily maximum and POT 3 and 4 when the large urban watersheds are included. This indicates that stormwater retention facilities are operated to effectively mitigate more severe events that are over the thresholds of POT1 and POT2, rather than the milder events that are over the thresholds of POT3 and POT4. Nevertheless, the results of the Mann-Whitney tests on daily peak discharge show that these facilities have less storage capacity than natural soil has, and this capacity is exceeded during the most extreme rainfall events.

\subsection{Seasonal flows, and the case of spring}

Tables 4 and 5 show that spring flows did not evolve very differently in urban and agricultural watersheds, contrary to the flows in other seasons. Spring is the season when soil moisture content is the highest, or in other words, when natural soils are least different from impervious surfaces. To the contrary, summer is when both types of soils are most different, and it is a season when the impact of land-use changes on peak flows are easier to detect (Yang et al., 2013), as evidenced by the results from this study.

However, peak discharge events are traditionally an occurrence in spring in the study area, so that even though all seasons except spring display significantly different evolutions between urban and agricultural peak flows, results in Table 5 are similar for annual peak flows and spring peak flows. This thought is inspired by Small et al. (2006), who solved the apparent paradox between increased precipitation in the Midwest and the paucity of detectable increases in peak discharge by suggesting that it might be due to increases in fall precipitation, which usually do not generate annual daily maxima.

Since streamflow is highest during spring, this is also when the impacts of effluent discharge on low flows are least felt. This is yet another factor that tends to attenuate the differences in the results between spring low flows in urban and agricultural watersheds. Furthermore, low flows usually occur in summer or fall, so the same kind of reasoning as before suggests that the evolution of annual low flows reflects the evolution of summer and fall low flows rather than that of spring low flows. Thus, 
the increases in low flows observed during summer and fall are expected to carry over to annual low flow indicators, as can be observed in the results.

\section{Conclusions}

The hydrological effects of urban development and climate variability are statistically assessed across different spatial scales in the Greater Chicago metropolitan area. The analysis is carried out using streamflow data at the outlets of 36 different watersheds, and for each of them, time series of 42 indicators are extracted. The crossing-scale statistical analysis is conducted both for of individual watersheds (at the outlet of those watersheds) and the groups of watersheds, through not only field significance testing but also by an original approach comparing the time evolution of the flow indicators in groups of urban and rural watersheds. On one hand, analyses at individual sites prove to be efficient in locating a step increase in streamflow at the end of the 1960s and distinguishing it from gradual changes. On the other hand, the differences in the comparative evolution of urban and agricultural watersheds are apparent with most of the streamflow indicators.

To analyze many time series crossing the various scales is very complex, and it represents one of the first efforts of this kind of analyses according to our knowledge The conclusions should be further validated by additional crossing-scale studies that focus on one particular type of flow indicators (e.g., peak flows). It is expected that such studies find generic ways to take into account non-hydrological data (e.g., volume and location of offstream reservoirs). Nevertheless, the present study clarifies the overall picture of streamflow change crossing the various scales in the Greater Chicago area.

Overall, results show that for the period of 1969-2007, urban development led to general streamflow increases in urban areas compared to agricultural ones. For all seasons except spring, when natural soils behave closest to an impervious surface, urban development led to increases in all flow quartiles, including maximum and minimum flows, as well as increases in mean flows. This seasonal pattern supports the idea that by turning natural soils into impervious areas, land-use change is, as expected, a factor in hydrological change. Moreover, the behavior of seasonal indicators is, at first glance, reflected in that of annual streamflow indicators. Indeed, the proposed Mann-Whitney test detects higher values of the statistic S in urban areas for all annual streamflow indicators, except for the case of peak flows, which have more equivocal results, perhaps due to the fact that high discharges happen primarily during spring.

Important as it is, land-use change is not the only explanatory factor for these results. Indeed, taken alone, it would lead to dwindling low flows and soaring peak discharges, but none of this was observed. The former is offset by effluent discharge and leakage of water withdrawn from Lake Michigan, while the latter is mitigated by the construction of stormwater management facilities. Both are established at different spatial scales and reflect adaptive measures to mitigate threats posed by urbanization in the

area: unsustainable on-site water supply due to the demographic pressure on one hand and expanding and more harmful flooding on the other hand.

This multi-spatial scale analysis suggests that there is a striking heterogeneity in the impacts of urban development on streamflow at the scale of small urban watersheds (under a hundred square kilometers in area), but this heterogeneity is reduced in larger basins. This suggests that impact 
studies should be carried out at a broader range of spatial scales in order to obtain a complete view of the impacts at the various scales at which different water and land management decisions are made. Such studies in other large cities of the world are necessary because climatic, as well as social, economic, and demographic conditions vary greatly from city to city. These factors can determine the pace and spatial extent of urban development, as well as the amount of water required for consumptive use and the amount of resources required to carry out adaptive responses such as the ones apparent in the Greater Chicago Area.

Finally, in terms of methodology, this analysis also illustrates why the impacts of anthropogenic interferences must be considered along with the local climate variability during the period of study. A step increase in annual precipitation around 1965 is detected in northeastern Illinois. This means that the impacts of urbanization can be best detected after this step increase, and the methodology for the analysis of streamflow is strongly influenced by this remark. Results reflect this approach: since impacts of urban development cannot be detected during the 1965-1972 period that corresponds with the step increase in precipitation, all the results presented in the three previous paragraphs come from our choice to specifically search for impacts after the step increase. Yet, climate variability across time and space remains an issue for the statistical analysis of direct anthropogenic inferences. For instance, the localized declines in summer rainfalls complicate the analysis of the impact of urbanization on low flows, and the fact that annual precipitation was higher during the 1970s and 1980s than in the subsequent period plays the same role with respect to the mean flows. In this respect, a major advantage of the Mann-Whitney test that was designed to compare the evolution of urban and agricultural watersheds lies in that it is independent on the variations of the hydro-climate: one only needs to assume that these variations are strongly correlated in space throughout the area of study.

\section{Acknowledgments}

This study was financially supported by U.S. National Science Foundation (NSF) projects, CMMI 0825654 and CBET 0747276. Thanks to Jory Hecht, Landon Marston for their insightful reviews and comments on earlier versions of this manuscript. Last but not least, the suggestions provided by two anonymous reviewers greatly improved our paper. 


\section{References}

Barringer, T.H., Reiser, R.G., Price, C.V., 1994. Potential effects of development on flow characterisitics of two new jersey streams. Water Resour. Bull. 30, 283-295.

Benjamini, Y., Hochberg, Y., 1995. Controlling the false discovery rate: A practical and powerful approach to multiple testing. Journal of the Royal Statistical Society. Series B (Methodological) 57, 289-300.

Benjamini, Y., Yekutieli, D., 2001. The control of the false discovery rate in multiple testing under dependency. The Annals of Statistics 29, 1165-1188.

Buishand, T.A., 1982. Some methods for testing the homogeneity of rainfall records. J. Hydrol. 58, $11-27$.

Burns, D., Vitvar, T., McDonnell, J., Hassett, J., Duncan, J., Kendall, C., 2005. Effects of suburban development on runoff generation in the croton river basin, new york, usa. J. Hydrol. 311, 266-281.

Changnon, S.A., Demissie, M., 1996. Detection of changes in streamflow and floods resulting from climate fluctuations and land use-drainage changes. Climatic Change 32, 411-421.

Claessens, L., Hopkinson, C., Rastetter, E., Vallino, J., 2006. Effect of historical changes in land use and climate on the water budget of an urbanizing watershed. Water Resour. Res. 42.

DeWalle, D.R., Swistock, B.R., Johnson, T.E., McGuire, K.J., 2000. Potential effects of climate change and urbanization on mean annual streamflow in the united states. Water Resour. Res. 36, 2655-2664.

Douglas, E.M., Vogel, R.M., Kroll, C.N., 2000. Trends in floods and low flows in the united states: impact of spatial correlation. Journal of Hydrology 240, 90-105.

Dow, C.L., DeWalle, D.R., 2000. Trends in evaporation and bowen ratio on urbanizing watersheds in eatern united states. Water Resour. Res. 36, 1835-1843.

Dziegielewski, B., Chowdhury, F.J., 2012. Scenario-based forecast of regional water demands in northeastern illinois. Journal of Wa , 80-89.

Ferguson, B.K., Suckling, P.W., 1990. Changing rainfall-runoff relationships in the urbanizing peachtree creek watershed, atlanta, georgia. Water Resour. Bull. 26, 313-322.

Glantz, M.H. (Ed.), 1999. Creeping Environmental Problems and Sustainable Development in the Aral Sea Basin. Cambridge University Press, Cambridge.

Grimm, N.B., Faeth, S.H., Golubiewski, N.E., Redman, C.L., Wu, J., Bai, X., Briggs, J.M., 2008. Global change and the ecology of cities. Science 319, 756-760.

Grimmond, C.S.B., Oke, T.R., 1986. Urban water balance, 2: Results from a suburb of vancouver, british columbia. Water Resour. Res. 22, 1404-1412.

Grimmond, C.S.B., Oke, T.R., Steyn, D.G., 1986. Urban water balance, 1: A model for daily totals. Water Resour. Res. 22, 1397-1403. 
Groisman, P.Y., Knight, R.W., Karl, T.R., 2001. Heavy precipitation and high streamflow in the contiguous united states: Trends in the twentieth century. Bull. Am. Meteorol. Soc. 82, 219-246.

Groisman, P.Y., Knight, R.W., Karl, T.R., 2012. Changes in intense precipitation over the central united states. J. Hydrometeorol. 13, 47-66.

Groisman, P.Y., Knight, R.W., Karl, T.R., Easterling, D.R., Sun, B., Lawrimore, J.H., 2004. Contemporary changes of the hydrological cycle over the contiguous united states: Trends derived from in situ observations. J. Hydrometeorol. 5, 64-85.

Hamed, K.H., Rao, A.R., 1998. A modified mann-kendall trend test for autocorrelated data. J. Hydrol. 204, 182-196.

Hejazi, M.I., Markus, M., 2009. Impact of urbanization and climate variability on floods in northeastern illinois. Journal of Hydrologic Engineering 14.

Hejazi, M.I., Moglen, G.E., 2007. Regression-based approach to low flow prediction in the maryland piedmont region under joint climate and land use change. Hydrol. Processes 21, 1793-1801.

Hejazi, M.I., Moglen, G.E., 2008. The effect of climate and land use change on flow duration in the maryland piedmont region. Hydrol. Processes 22, 4710-4722.

Hollis, G.E., 1975. The effect of urbanization on floods of different recurrence intervals. Water Resour. Res. 11, 431-435.

Hurkmans, R.T.W.L., Terink, W., Uijlenhoet, R., Moors, E.J., Troch, P.A., Verburg, P.H., 2009. Effects of land use changes on streamflow generation in the rhine basin. Water Resour. Res. 45.

Karl, T.R., Knight, R.W., 1998. Secular trends of precipitation amount, frequency, and intensity in the united states. Bull. Am. Meteorol. Soc. 79, 231-241.

Katz, R.W., Parlange, M.B., Naveau, P., 2002. Statistics of extremes in hydrology. Adv. Water Resour. 25, 1287-1304.

Kendall, M.G. (Ed.), 1975. Rank correlation methods. C. Griffin, London. 2nd edition.

Lazaro, T.R., 1976. Nonparametric statistical analysis of annual peak flow data from a recently urbanized watershed. Water Resour. Bull. 12, 101-107.

Lettenmaier, D.P., Wood, E.F., Walls, J.R., 1994. Hydro-climatological trends in the continental united states, 1948-1988. J. Climate 7, 586-607.

Lins, H.F., Slack, J.R., 1999. Streamflow trends in the united states. Geophys. Res. Lett. 26, 227-230.

Lins, H.F., Slack, J.R., 2005. Seasonal and regional characteristics of u.s. streamflow trends in the united states from 1940 to 1999. Phys. Geogr. 26, 489-501.

Liu, J., Dietz, T., Carpenter, S., Folke, C., Alberti, M., Redman, C., Schneider, S., Ostrom, E., Pell, A., Lubchenco, J., Taylor, W., Ouyang, Z., Deadman, P., Kratz, T., Provencher, W., 2007. Coupled human and natural systems. Ambio 36. 
Livezey, R.E., Chen, W.Y., 1983. Statistical field significance and its determination by monte carlo techniques. Monthly Weather Review 111, 46-59.

Lombard, F., 1987. Rank tests for changepoint problems. Biometrika 74, 615-624.

Mann, H., 1945. Non-parametric tests against trend. Econometrica 13, 245-259.

Mann, H.B., Whitney, D.R., 1947. On a test of whether one of two random variables is stochastically larger than the other. Ann. Math. Stat. 18, 50-60.

Markus, M., Angel, J.R., Yang, L., Hejazi, M., 2007. Changing estimates of design precipitation in northeastern illinois: Comparison between different sources and sensitivity analysis. J. Hydrol. 347, $211-222$.

McCabe, G., Wolock, D., 2002. A step increase in streamflow in the conterminous united states. Geophys. Res. Lett. 29.

McConkey, S., Bartosova, A., Lin, L.C., Andrew, K., Machesky, M., Jennings, C., 2004. Fox River Watershed Investigation - Stratton Dam to the Illinois River: Water Quality Issues and Data Report to the Fox River Study Group, Inc. Technical Report CR 2004-2006. Illinois State Water Survey. Champaign, IL.

McCormick, B.C., Eshleman, K.N., Griffith, J.L., Townsend, P.A., 2009. Detection of flooding responses at the river basin scale enhanced by land-use change. Water Resour. Res. 45.

Meyer, S.C., 2005. Analysis of base flow trends in urban streams, northeastern illinois, usa. Hydrogeol. J. $13,871-885$.

Milly, P.C.D., 1994a. Climate, interseasonal storage of soil water, and the annual water balance. Adv. Water Resour. 17, 19-24.

Milly, P.C.D., 1994b. Climate, soil water storage, and the average annual water balance. Water Resour. Res. 30, 2143-2156.

Pettitt, A.N., 1979. A non-parametric approach to the change point problem. Appl. Stat.-J. Roy. St. C $28,126-135$.

Pryor, S.C., Howe, J.A., Kunkel, K.E., 2009. How spatially coherent and statistically robust are temporal changes in extreme precipitation in the contiguous usa? Int. J. Climatol. 29, 31-45.

Quessy, J.F., Favre, A.C., Said, M., Champagne, M., 2011. Statistical inference in lombard's smoothchange model. Environmetrics 22, 882-893.

Renard, B., Lang, M., Blois, P., 2006. Statistical analysis of extreme events in a non-stationaty context via a bayesian framework: case study with peak-over-threshold data. Stoch. Env. Res. Risk A. 21, $97-112$.

Renard, B., Lang, M., Dupeyrat, A., Mestre, O., Niel, H., Sauquet, E., Prudhomme, C., Parey, S., Paquet, E., Neppel, L., Gailhard, J., 2008. Regional methods for trend detection: Assessing field significance and regional consistency. Water Resources Research 44. 
Rougé, C., Ge, Y., Cai, X., 2013. Detecting gradual and abrupt changes in hydrological records. Adv. Water Resour. 53, 33-44.

Ryberg, K.R., Lin, W., Vecchia, A.V., 2014. Impact of climate variability on runoff in the north central united states. J. Hydraul. Eng. 19, 148-158.

Sankarasubramanian, A., Vogel, R.M., 2003. Hydroclimatology of the continental united states. Geophys. Res. Lett. 30.

Sen, P.K., 1968. Estimates of the regression coefficient based on kendall's tau. J. Am. Stat. Assoc. 63, 1379-1389.

Singh, K.P., Ramamurthy, G.S., 1993. 7-Day, 10-Year Low Flows of Streams in Northeastern Illinois. Technical Report. Illinois State Water Survey. Contract Report 545.

Small, D., Islam, S., Vogel, R.M., 2006. Trends in precipitation and streamflow in the eastern u.s.: Paradox or perception? Geophys. Res. Lett. 33.

Smith, B.K., Smith, J.A., Baeck, M.L., Villarini, G., Wright, D.B., 2013. The spectrum of storm event hydrologic response in urban watersheds. Water Resour. Res. 49, 1-15.

Smith, K., Richman, M.B., 1993. Recent hydroclimatic fluctuations and their effects on water resources in illinois. Climatic Change 24, 249-269.

Solo-Gabriele, H., Perkins, F.E., 1997. Streamflow and suspended sediment transport in an urban environment. J. Hydraul. Eng. 123, 807-811.

Svensson, C., Kundzewicz, Z.W., Maurer, T., 2005. Trend detection in river flow series: 2. flood and low-flow index series. Hydrol. Sci. J. 50, 811-824.

Theil, H., 1950. A rank-invariant method of linear and polynomial regression analysis, i, ii and iii. Nederl. Akad. Wetensch. Proc. 53, 386-392, 521-525 and 1397-1412.

Tomer, M.D., Schilling, K.E., 2009. A simple approach to distinguish land-use and climate-change effects on watershed hydrology. Journal of Hydrology 376, 24-33.

Villarini, G., Scoccimarro, E., Gualdi, S., 2013a. Projections of heavy rainfall over the central united states based on cmip5 models. Atmos. Sci. Lett. 14, 200-205.

Villarini, G., Serinaldi, F., Smith, J.A., Krajewski, W.F., 2009a. On the stationarity of annual flood peaks in the continental united states during the 20th century. Water Resour. Res. 45.

Villarini, G., Smith, J.A., Baeck, M.L., Smith, B.K., Sturdevant-Rees, P., 2013b. Hydrologic analyses of the july 17-18, 1996, flood in chicago and the role of urbanization. J. Hydraul. Eng. 18, 205-259.

Villarini, G., Smith, J.A., Serinaldi, F., Bales, J., Bates, P.D., Krajewski, W.F., 2009b. Flood frequency analysis for nonstationary annual peak records in an urban drainage basin. Adv. Water Resour. 32, 1255-1266. 
Villarini, G., Smith, J.A., Vecchi, G.A., 2013c. Changing frequency of heavy rainfall over the central united states. J. Climate 26, 343-350.

Vörösmarty, C.J., Green, P., Salisbury, J., Lammers, R.B., 2000. Global water resources: Vulnerability from climate change and population growth. Science 289, 284-288.

Wang, D., Cai, X., 2009. Detecting human inferences to low flows through base flow recession analysis. Water Resour. Res. 45.

Wilks, D.S., 2006. On "field significance" and the false discovery rate. Journal of Applied Meteorology and Climatology 45, 1181-1189.

Xiong, L., Guo, S., 2004. Trend test and change-point detection for the annual discharge series of the yangtze river at the yichang hydrological station. Hydrol. Sci. J. 49, 99-114.

Yang, L., Smith, J.A., Wright, D.B., Baeck, M.L., Villarini, G., Tian, F., H.Hu, 2013. Urbanization and climate change: An examination of nonstationarities in urban flooding. J. Hydrometeorol. 14, 1791-1809.

Yeh, C.H., Labadie, J.W., 1997. Multiobjective watershed-level planning of storm water detention systems. J. Water Resour. Plann. Manage. 123, 336-343.

Yue, S., Pilon, P., Phinney, B., Cavadias, G., 2002. The influence of autocorrelation on the ability to detect trend in hydrological series. Hydrol. Processes 16, 1807-1829.

Yue, S., Wang, C.Y., 2002. Applicability of prewhitening to eliminate the influence of serial correlation on the mann-kendall test. Water Resour. Res. 38.

Zehe, E., Sivapalan, M., 2009. Threshold behavior in hydrological systems as (human) geo-ecosystems: manifestations, controls, implications. Hydrol. Earth Syst. Sci. 13, 1273-1297. 


\section{List of Tables}

1 List of the eight NOAA rainfall gages used in this study. Letters are to locate them on

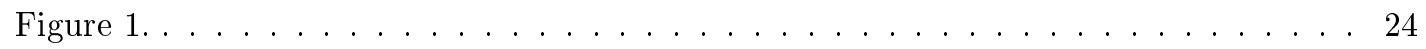

2 Population growth rates in Northeastern Illinois . . . . . . . . . . . . . . . . . . 24

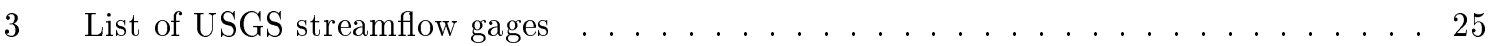

4 Summary of the analysis of streamflow over the $1953-2007$ period. Ch. stands for statistically significant changes $(\alpha=0.05)$, with decreases between parentheses, and $p_{m}$ is the median date of change among the time-series that exhibit change. Bold figures indicate field significance of the changes. . . . . . . . . . . . . . . 26

5 Analysis of streamflow over the $1969-2007$ period. Field significance of change is indicated by bold figures, and the number of changes that are decreases are noted between the parentheses. All of the significant differences in evolution between urban and agricultural watersheds detected by the Mann-Whitney test are cases where urban flow indicators displayed a comparative increase . . . . . . . . . . . . . . 27 


\section{List of Figures}

1 Map of rainfall and streamflow gages used. The background is land use: urban areas are shaded in light pink. Rainfall gages have the same letter as in Table 1, streamflow gages the same number as in Table 3. Thus, gages 1 to 10 are agricultural watersheds (Group I), gages 11 to 20 are large urban watersheds (Group II), and gages 21 to 36 are small urban watersheds (Group III) . . . . . . . . . . . . . . . . . 28

2 Cumulative deviations from the divisional annual rainfall from 1908-1964. Cumulative deviations from rainfall gages have been standardized so as to be zero in 1964. Record spans $1908-2007 . \ldots \ldots \ldots$. . . . . . . . . . . . . . . . . 29

3 For each decade, departures from the mean annual precipitation for the NCDC Northeastern Illinois division. Decades are 1908 - 1917, 1918-1927, and so on until 1998-2007. 30

4 Summer precipitations total for the rainfall gage 119029 at Waukegan. The grey line is the Sen-Theil (Theil, 1950; Sen, 1968) estimate of the linear trend. . . . . . . . . . . . 31

5 Spatial patterns of change in and around the Greater Chicago Area for $a$ ) mean annual flow, b) 7-day minimum flow and $c$ ) annual daily maximum flow. . . . . . . . . . 32

6 Mean annual flow (above) and 7-day minimum flow (below) for Salt Creek at the 05531500 gage. . . . . . . . . . . . . . . . . . . 33

$7 \quad$ 1953-2007 time series of the 7-day minimum flows at four urban gages. (a) and (b) are the outlets of the two largest urban watersheds while $(c)$ and $(d)$ correspond to small

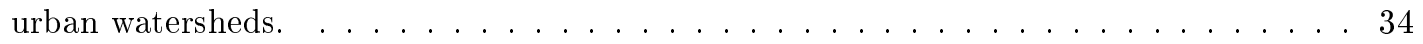

8 Construction of storm retention reservoirs and peak flow occurrence in the Addison Creek basin (upstream of gage 05532000) . . . . . . . . . . . . . . . . 35

9 Mann-Kendall statistics $S$ for all the gages (numbered as in Table 3). The red lines represent statistical significance at an individual gage at the $5 \%$ significance level; the dotted black lines delimit the three groups of gages: agricultural, large urban and small

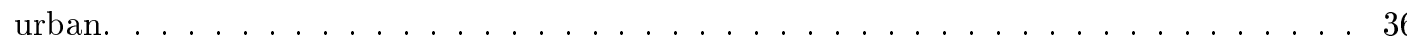




\begin{tabular}{|c|cc|cc|c|}
\hline NOAA ID & & Station name & Latitude & Longitude & Period of record \\
\hline 116616 & A & Park Forest & $41^{\circ} 29^{\prime}$ & $-87^{\circ} 40^{\prime}$ & $1953-2007$ \\
114530 & B & Joliet Brandom Rd Dam & $41^{\circ} 30^{\prime}$ & $-88^{\circ} 06^{\prime}$ & $1941-2007$ \\
111577 & C & Chicago Midway AP 3SW & $41^{\circ} 44^{\prime}$ & $-87^{\circ} 46^{\prime}$ & $1942-2007$ \\
110338 & D & Aurora & $41^{\circ} 46^{\prime}$ & $-88^{\circ} 18^{\prime}$ & $1900-2007$ \\
119221 & E & Wheaton 3 SE & $41^{\circ} 48^{\prime}$ & $-88^{\circ} 04^{\prime}$ & $1937-2006$ \\
111549 & F & Chicago O'Hare Intl. Ap. & $41^{\circ} 59^{\prime}$ & $-87^{\circ} 56^{\prime}$ & $1959-2007$ \\
112736 & G & Elgin & $42^{\circ} 03^{\prime}$ & $-88^{\circ} 17^{\prime}$ & $1931-2007$ \\
119029 & H & Waukegan & $42^{\circ} 20^{\prime}$ & $-87^{\circ} 52^{\prime}$ & $1931-2001$ \\
\hline
\end{tabular}

Table 1: List of the eight NOAA rainfall gages used in this study. Letters are to locate them on Figure 1.

\begin{tabular}{|c|ccc|ccc|}
\hline Counties & \multicolumn{3}{|c|}{ Population } & $(\times 0.1 \mathrm{M})$ & \multicolumn{3}{c|}{ Population Increase (\%) } \\
& 1960 & 1980 & 2000 & $1960-1980$ & $1980-2000$ & $1960-2000$ \\
\hline DuPage & 3.1 & 6.6 & 9.0 & 110.2 & 37.2 & 188.4 \\
Kane & 2.1 & 2.8 & 4.0 & 33.7 & 45.2 & 94.1 \\
Lake & 2.9 & 4.4 & 6.4 & 50.0 & 46.3 & 119.4 \\
McHenry & 0.8 & 1.5 & 2.6 & 75.6 & 75.9 & 208.8 \\
Will & 1.9 & 3.2 & 5.0 & 69.3 & 54.8 & 162.1 \\
\hline Total suburban & 10.9 & 18.5 & 27.1 & 69.5 & 46.8 & 148.8 \\
Cook & 51.3 & 52.5 & 53.8 & 2.4 & 2.3 & 4.8 \\
\hline Total metropolitan area & 62.2 & 71.0 & 80.9 & 14.2 & 13.9 & 30.1 \\
\hline
\end{tabular}

Table 2: Population growth rates over 20 year periods for several counties over Northeastern Illinois. County-wide census data. 


\begin{tabular}{|c|c|c|c|c|c|c|c|}
\hline & & & River & Site & $\begin{array}{c}\text { Gage } \\
\text { number }\end{array}$ & $\begin{array}{c}\text { Drainage } \\
\text { area }\left(\mathrm{km}^{2}\right)\end{array}$ & $\begin{array}{l}\text { Record } \\
\text { starts in }\end{array}$ \\
\hline \multirow{10}{*}{ 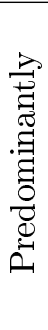 } & \multirow{10}{*}{ 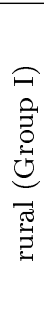 } & 1 & Fox River & Dayton & 05552500 & 6843 & 1915 \\
\hline & & 2 & Fox River & Algonquin & 05550000 & 3634 & 1916 \\
\hline & & 3 & Vermilion River & Leonore & 05555300 & 3240 & 1932 \\
\hline & & 4 & Kankakee River & Wilmington & 05527500 & 13338 & 1936 \\
\hline & & 5 & Kishwaukee River & Belvidere & 05438500 & 1393 & 1940 \\
\hline & & 6 & SB Kishwaukee River ${ }^{1}$ & Fairdale & 05439500 & 1002 & 1940 \\
\hline & & 7 & Fox River & New Munster & 05545750 & 2100 & 1940 \\
\hline & & 8 & Ferson Creek & St Charles & 05551200 & 134 & 1961 \\
\hline & & 9 & Blackberry Creek & Yorkville & 05551700 & 182 & 1961 \\
\hline & & 10 & Nippersink Creek & Spring Grove & 05548280 & 497 & 1967 \\
\hline \multirow{10}{*}{ 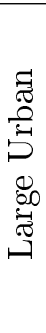 } & \multirow{10}{*}{ 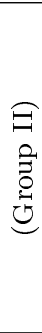 } & 11 & Des Plaines River & Des Plaines & 05529000 & 932 & 1941 \\
\hline & & 12 & DuPage River & Shorewood & 05540500 & 839 & 1941 \\
\hline & & 13 & Des Plaines River & Riverside & 05532500 & 1631 & 1944 \\
\hline & & 14 & Hickory Creek & Joliet & 05539000 & 278 & 1945 \\
\hline & & 15 & Salt Creek & Western Springs & 05531500 & 298 & 1946 \\
\hline & & 16 & Little Calumet River & South Holland & 05536290 & 539 & 1948 \\
\hline & & 17 & Thorn Creek & Thornton & 05536275 & 269 & 1949 \\
\hline & & 18 & NB Chicago River ${ }^{1}$ & Niles & 05536000 & 259 & 1951 \\
\hline & & 19 & Des Plaines River & Gurnee & 05528000 & 601 & 1969 \\
\hline & & 20 & WB DuPage River ${ }^{1}$ & Warrenville & 05540095 & 234 & 1969 \\
\hline \multirow{16}{*}{ 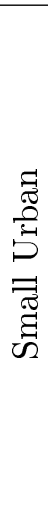 } & \multirow{16}{*}{ 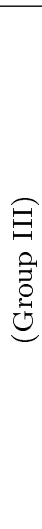 } & 21 & Deer Creek & Chicago Heights & 05536235 & 60 & 1949 \\
\hline & & 22 & Butterfield Creek & Flossmoor & 05536255 & 61 & 1949 \\
\hline & & 23 & Weller Creek & Des Plaines & 05530000 & 34 & 1951 \\
\hline & & 24 & Midlothian Creek & Oak Forest & 05536340 & 33 & 1951 \\
\hline & & 25 & Addison Creek & Bellwood & 05532000 & 46 & 1952 \\
\hline & & 26 & Flag Creek & Willow Springs & 05533000 & 43 & 1952 \\
\hline & & 27 & Skokie River & Lake Forest & 05535000 & 34 & 1952 \\
\hline & & 28 & Tinley Creek & Palos Park & 05536500 & 29 & 1952 \\
\hline & & 29 & Long Run & Lemont & 05537500 & 54 & 1952 \\
\hline & & 30 & Poplar Creek & Elgin & 05550500 & 91 & 1952 \\
\hline & & 31 & Buffalo Creek & Wheeling & 05528500 & 51 & 1953 \\
\hline & & 32 & McDonald Creek & Mount Prospect & 05529500 & 21 & 1953 \\
\hline & & 33 & NB Chicago River ${ }^{1}$ & Deerfield & 05534500 & 51 & 1953 \\
\hline & & 34 & WFNB Chicago River ${ }^{1}$ & Northbrook & 05535500 & 30 & 1953 \\
\hline & & 35 & WB DuPage River ${ }^{1}$ & West Chicago & 05539900 & 74 & 1962 \\
\hline & & 36 & Skokie River & Highland Park & 05535070 & 57 & 1968 \\
\hline
\end{tabular}

${ }^{1}$ B: Branch; F: Fork; N: North; W: West

Table 3: List of the 36 USGS streamflow gages with continuous records used for this study. They are classified by land-use type, first year of record used in this study, and gage number. Figure 1 shows the location of these stations. Records are ended in 2007. 


\begin{tabular}{|c|c|c|c|c|c|c|c|c|c|c|c|c|c|}
\hline & \multirow[b]{2}{*}{ Indicator } & \multicolumn{4}{|c|}{ Predominantly rural (I) } & \multicolumn{4}{|c|}{ Large urban (II) } & \multicolumn{4}{|c|}{ Small urban (III) } \\
\hline & & Ch. $(\searrow)$ & $G_{1}$ & $G_{2}$ & $p_{m}$ & Ch. $(\searrow)$ & $G_{1}$ & $G_{2}$ & $p_{m}$ & Ch. $(\searrow)$ & $G_{1}$ & $G_{2}$ & $p_{m}$ \\
\hline \multirow{18}{*}{ 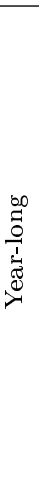 } & Mean & 7 & 0 & 0 & 1972 & 8 & 2 & 2 & 1972 & 12 & 3 & 4 & 1970,5 \\
\hline & $Q_{0}$ & 6 & 0 & 0 & 1970 & 8 & 5 & 4 & 1978 & 11(2) & 6 & 4 & 1978 \\
\hline & 7 -day $\min$ & 7 & 0 & 0 & 1970 & 8 & 5 & 4 & 1979 & 11(1) & 5 & 5 & 1978 \\
\hline & $Q_{10}$ & 6 & 0 & 0 & 1972 & 8 & 5 & 4 & 1978,5 & $12(1)$ & 6 & 5 & 1978 \\
\hline & $Q_{20}$ & 6 & 0 & 0 & 1972 & 8 & 5 & 3 & 1979 & $12(1)$ & 7 & 7 & 1969 \\
\hline & $Q_{30}$ & 7 & 0 & 0 & 1969 & 8 & 5 & 3 & 1979 & 10 & 5 & 5 & 1975,5 \\
\hline & $Q_{40}$ & 5 & 0 & 0 & 1969 & 8 & 3 & 3 & 1979 & 11 & 5 & 7 & 1970 \\
\hline & $Q_{50}$ & 6 & 0 & 0 & 1970,5 & 8 & 2 & 3 & 1972 & 11 & 4 & 8 & 1972 \\
\hline & $Q_{60}$ & 6 & 0 & 0 & 1970,5 & 8 & 2 & 4 & 1972 & 11 & 1 & 8 & 1970 \\
\hline & $Q_{70}$ & 6 & 0 & 0 & 1972 & 8 & 2 & 3 & 1972 & 12 & 1 & 5 & 1972 \\
\hline & $Q_{80}$ & 7 & 0 & 0 & 1972 & 8 & 0 & 3 & 1972 & 12 & 2 & 2 & 1969,5 \\
\hline & $Q_{90}$ & 6 & 0 & 0 & 1971,5 & 8 & 0 & 3 & 1972 & 13 & 3 & 1 & 1972 \\
\hline & $Q_{100}$ & 5 & 0 & 0 & 1971 & 4 & 1 & 1 & 1982 & 10 & 3 & 2 & 1976,5 \\
\hline & $P O T 1$ & 4 & 0 & 1 & 1971 & 6 & 0 & 0 & 1972 & 8 & 3 & 2 & 1979 \\
\hline & POT 2 & 7 & 0 & 2 & 1972 & 5 & 0 & 3 & 1972 & 11 & 3 & 4 & 1972 \\
\hline & РOT3 & 5 & 0 & 0 & 1971 & 6 & 1 & 2 & 1972 & 11 & 4 & 3 & 1972 \\
\hline & POT 4 & 5 & 0 & 0 & 1972 & 5 & 2 & 2 & 1972 & 13 & 2 & 2 & 1969 \\
\hline & POT5 & 4 & 0 & 0 & 1972 & 6 & 2 & 3 & 1969 & 12 & 2 & 4 & 1969,5 \\
\hline \multirow{6}{*}{$\stackrel{\Phi}{\stackrel{ \pm}{\leftrightarrows}}$} & Mean & 3 & 0 & 0 & 1971 & 6 & 1 & 3 & 1973 & 8 & 1 & 2 & 1973 \\
\hline & $Q_{0}$ & 6 & 0 & 0 & 1973 & 8 & 6 & 5 & 1979 & 10 & 4 & 2 & 1978,5 \\
\hline & $Q_{25}$ & 6 & 0 & 0 & 1983 & 7 & 6 & 6 & 1983 & 11 & 4 & 3 & 1983 \\
\hline & $Q_{50}$ & 6 & 0 & 0 & 1982 & 6 & 3 & 4 & 1983 & 10 & 2 & 3 & 1982 \\
\hline & $Q_{75}$ & 3 & 0 & 0 & 1971 & 6 & 1 & 2 & 1973 & 7 & 1 & 1 & 1973 \\
\hline & $Q_{100}$ & 2 & 0 & 0 & 1973 & 4 & 0 & 2 & 1972 & 8 & 0 & 5 & 1974 \\
\hline \multirow{6}{*}{ 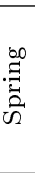 } & Mean & 3 & 0 & 0 & 1972 & $\mathbf{5}$ & 0 & 2 & 1969 & 3 & 0 & 1 & 1966 \\
\hline & $Q_{0}$ & 5 & 0 & 0 & 1969 & 6 & 1 & 3 & 1969 & $7(2)$ & 2 & 1 & 1972 \\
\hline & $Q_{25}$ & 3 & 0 & 0 & 1969 & 5 & 0 & 3 & 1969 & $4(1)$ & 1 & 1 & 1972,5 \\
\hline & $Q_{50}$ & 3 & 0 & 0 & 1972 & 5 & 0 & 2 & 1969 & $4(1)$ & 1 & 1 & 1973,5 \\
\hline & $Q_{75}$ & 3 & 0 & 0 & 1969 & 4 & 0 & 2 & 1967,5 & $5(1)$ & 1 & 2 & 1969 \\
\hline & $Q_{100}$ & 0 & 0 & 0 & 0 & 0 & 0 & 0 & 0 & 2 & 0 & 0 & 1981,5 \\
\hline \multirow{6}{*}{ 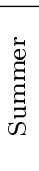 } & Mean & 4 & 0 & 0 & 1968 & 8 & 2 & 4 & 1977 & 11 & 3 & 5 & 1977 \\
\hline & $Q_{0}$ & 5 & 0 & 0 & 1972 & 7 & 5 & 2 & 1978 & $12(2)$ & 5 & 4 & 1975,5 \\
\hline & $Q_{25}$ & 6 & 0 & 0 & 1970 & 8 & 5 & 3 & 1977,5 & $12(2)$ & 6 & 4 & 1977,5 \\
\hline & $Q_{50}$ & 6 & 0 & 0 & 1970 & 8 & 4 & 3 & 1977,5 & 11 & 5 & 7 & 1977 \\
\hline & $Q_{75}$ & 6 & 0 & 0 & 1968 & 8 & 1 & 4 & 1977 & 12 & 3 & 9 & 1977 \\
\hline & $Q_{100}$ & 1 & 0 & 0 & 1968 & 6 & 0 & 5 & 1976 & 10 & 3 & 3 & 1978 \\
\hline \multirow{6}{*}{$\overline{\widetilde{\sigma}}$} & Mean & 3 & 0 & 0 & 1972 & 7 & 2 & 0 & 1982 & 11 & 2 & 0 & 1982 \\
\hline & $Q_{0}$ & 5 & 0 & 0 & 1970 & 7 & 4 & 4 & 1978 & 11(2) & 4 & 4 & 1977 \\
\hline & $Q_{25}$ & 2 & 0 & 0 & 1972 & 8 & 3 & 3 & 1979 & 11(1) & 3 & 3 & 1972 \\
\hline & $Q_{50}$ & 5 & 0 & 0 & 1972 & 8 & 2 & 1 & 1980 & 11 & 1 & 2 & 1982 \\
\hline & $Q_{75}$ & 3 & 0 & 0 & 1981 & 8 & 2 & 0 & 1981 & 12 & 1 & 0 & 1982 \\
\hline & $Q_{100}$ & 4 & 0 & 0 & 1972 & 8 & 1 & 0 & 1980,5 & 13 & 0 & 1 & 1979 \\
\hline \multicolumn{2}{|c|}{ Sample size } & \multicolumn{4}{|c|}{7} & \multicolumn{4}{|c|}{8} & \multicolumn{4}{|c|}{14} \\
\hline
\end{tabular}

Table 4: Summary of the analysis of streamflow over the 1953-2007 period. Ch. stands for statistically significant changes $(\alpha=0.05)$, with decreases between parentheses, and $p_{m}$ is the median date of change among the time-series that exhibit change. Bold figures indicate field significance of the changes. 


\begin{tabular}{|c|c|c|c|c|c|c|c|}
\hline & \multirow[b]{2}{*}{ Indicator } & \multicolumn{3}{|c|}{ Significant changes $(\searrow)$} & \multicolumn{3}{|c|}{ Significant difference in $S_{0}$} \\
\hline & & I & II & III & I vs. $(\mathrm{II}+\mathrm{III})$ & I vs. II & I vs. III \\
\hline \multirow{18}{*}{ 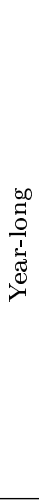 } & Mean & 0 & 2 & 4 & 1 & 1 & 1 \\
\hline & $Q_{0}$ & $1(1)$ & $8(1)$ & $10(3)$ & 0 & 1 & 0 \\
\hline & 7-day $\min$ & $1(1)$ & 7 & $\mathbf{9 ( 2 )}$ & 1 & 1 & 1 \\
\hline & $Q_{10}$ & 0 & 7 & $9(2)$ & 1 & 1 & 1 \\
\hline & $Q_{20}$ & 0 & 7 & $10(2)$ & 1 & 1 & 1 \\
\hline & $Q_{30}$ & $1(1)$ & 7 & $9(2)$ & 1 & 1 & 1 \\
\hline & $Q_{40}$ & 0 & 3 & $7(1)$ & 1 & 1 & 1 \\
\hline & $Q_{50}$ & $1(1)$ & 2 & 4 & 1 & 1 & 1 \\
\hline & $Q_{60}$ & $1(1)$ & 2 & 1 & 1 & 1 & 1 \\
\hline & $Q_{70}$ & 0 & 2 & 1 & 1 & 1 & 1 \\
\hline & $Q_{80}$ & $1(1)$ & $1(1)$ & 2 & 1 & 1 & 1 \\
\hline & $Q_{90}$ & $1(1)$ & $1(1)$ & 3 & 1 & 1 & 1 \\
\hline & $Q_{100}$ & 0 & $3(1)$ & $6(1)$ & 1 & 1 & 0 \\
\hline & POT 1 & 0 & 1 & $8(3)$ & 0 & 0 & 0 \\
\hline & POT2 & 0 & 1 & $7(2)$ & 0 & 0 & 0 \\
\hline & POT3 & 0 & 2 & $8(3)$ & 1 & 1 & 0 \\
\hline & POT 4 & 0 & 3 & $4(1)$ & 1 & 1 & 0 \\
\hline & POT5 & $2(2)$ & 3 & $4(1)$ & 0 & 0 & 0 \\
\hline \multirow{6}{*}{ 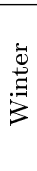 } & Mean & 0 & 2 & 2 & 1 & 1 & 1 \\
\hline & $Q_{0}$ & 0 & 8 & $7(1)$ & 1 & 1 & 1 \\
\hline & $Q_{25}$ & 0 & 8 & 6 & 1 & 1 & 1 \\
\hline & $Q_{50}$ & 0 & 4 & 3 & 1 & 1 & 1 \\
\hline & $Q_{75}$ & 0 & 1 & 2 & 1 & 1 & 0 \\
\hline & $Q_{100}$ & 0 & 0 & 0 & 1 & 1 & 1 \\
\hline \multirow{6}{*}{ 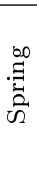 } & Mean & 0 & 0 & $1(1)$ & 1 & 1 & 0 \\
\hline & $Q_{0}$ & $1(1)$ & $2(1)$ & $7(6)$ & 0 & 0 & 0 \\
\hline & $Q_{25}$ & 0 & 0 & $3(2)$ & 0 & 1 & 0 \\
\hline & $Q_{50}$ & 0 & 0 & $2(1)$ & 0 & 0 & 0 \\
\hline & $Q_{75}$ & 0 & $1(1)$ & $1(1)$ & 0 & 0 & 0 \\
\hline & $Q_{100}$ & 0 & 0 & $2(2)$ & 0 & 0 & 0 \\
\hline \multirow{6}{*}{ 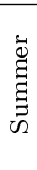 } & Mean & 0 & 2 & 3 & 1 & 1 & 1 \\
\hline & $Q_{0}$ & $1(1)$ & 6 & $10(4)$ & 1 & 1 & 0 \\
\hline & $Q_{25}$ & $1(1)$ & 7 & $8(2)$ & 1 & 1 & 1 \\
\hline & $Q_{50}$ & 1(1) & 5 & $6(1)$ & 1 & 1 & 1 \\
\hline & $Q_{75}$ & 0 & 1 & 3 & 1 & 1 & 1 \\
\hline & $Q_{100}$ & 1 & 0 & 4 & 1 & 1 & 1 \\
\hline \multirow{6}{*}{ 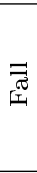 } & Mean & 0 & 2 & 2 & 1 & 1 & 1 \\
\hline & $Q_{0}$ & $1(1)$ & 5 & $6(2)$ & 1 & 1 & 1 \\
\hline & $Q_{25}$ & 0 & 3 & $5(2)$ & 1 & 1 & 1 \\
\hline & $Q_{50}$ & 0 & 2 & 1 & 1 & 1 & 1 \\
\hline & $Q_{75}$ & 0 & 2 & 1 & 1 & 1 & 1 \\
\hline & $Q_{100}$ & 0 & 2 & 0 & 1 & 1 & 0 \\
\hline \multicolumn{2}{|c|}{ Sample size } & 10 & 10 & 16 & & & \\
\hline
\end{tabular}

Table 5: Analysis of streamflow over the $1969-2007$ period. Field significance of change is indicated by bold figures, and the number of changes that are decreases are noted between the parentheses. All of the significant differences in evolution between urban and agricultural watersheds detected by the Mann-Whitney test are cases where urban flow indicators displayed a comparative increase. 


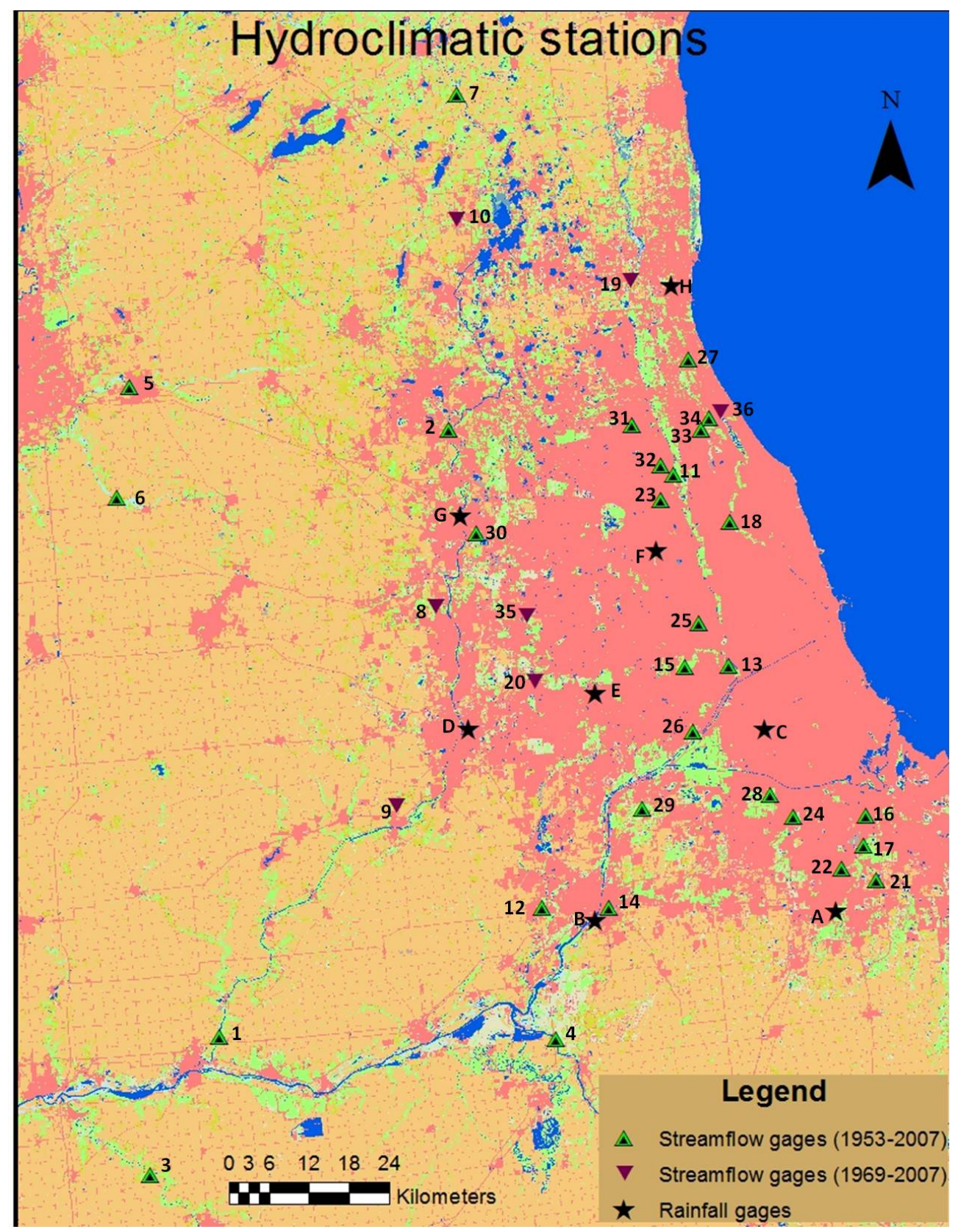

Figure 1: Map of rainfall and streamflow gages used. The background is land use: urban areas are shaded in light pink. Rainfall gages have the same letter as in Table 1, streamflow gages the same number as in Table 3. Thus, gages 1 to 10 are agricultural watersheds (Group I), gages 11 to 20 are large urban watersheds (Group II), and gages 21 to 36 are small urban watersheds (Group III). 


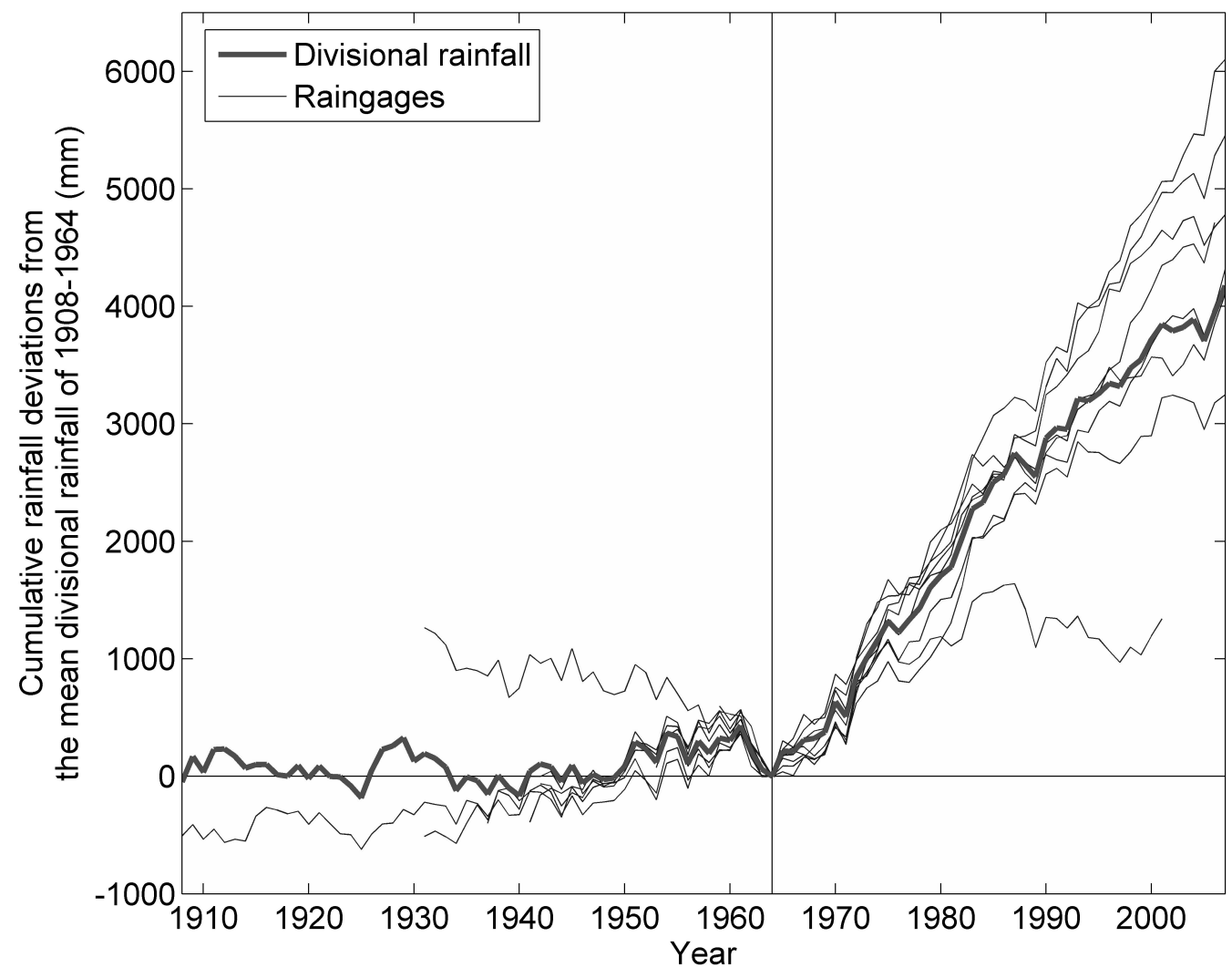

Figure 2: Cumulative deviations from the divisional annual rainfall from 1908 - 1964. Cumulative deviations from rainfall gages have been standardized so as to be zero in 1964. Record spans 1908-2007. 


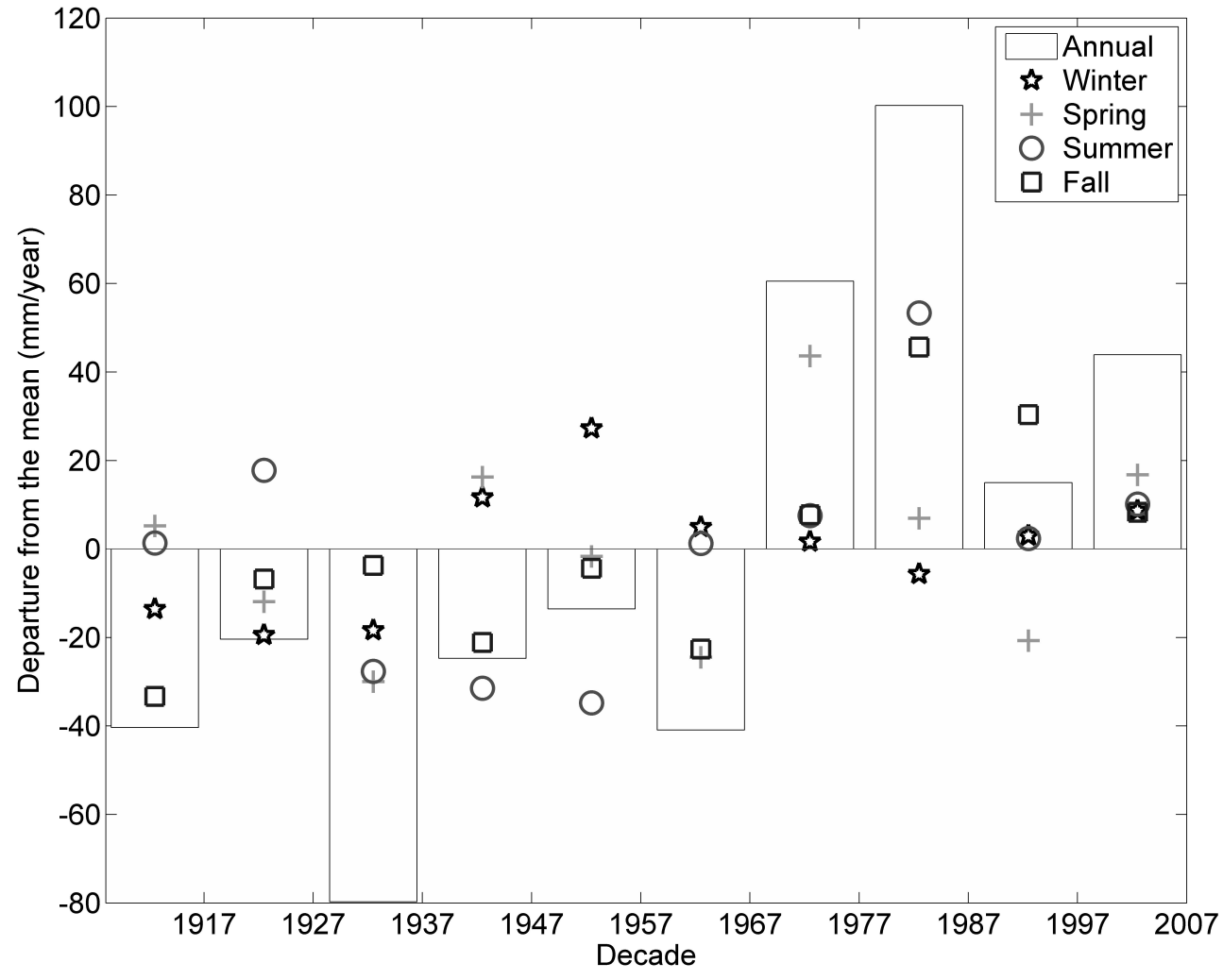

Figure 3: For each decade, departures from the mean annual precipitation for the NCDC Northeastern Illinois division. Decades are 1908 - 1917, 1918 - 1927, and so on until 1998 - 2007. 


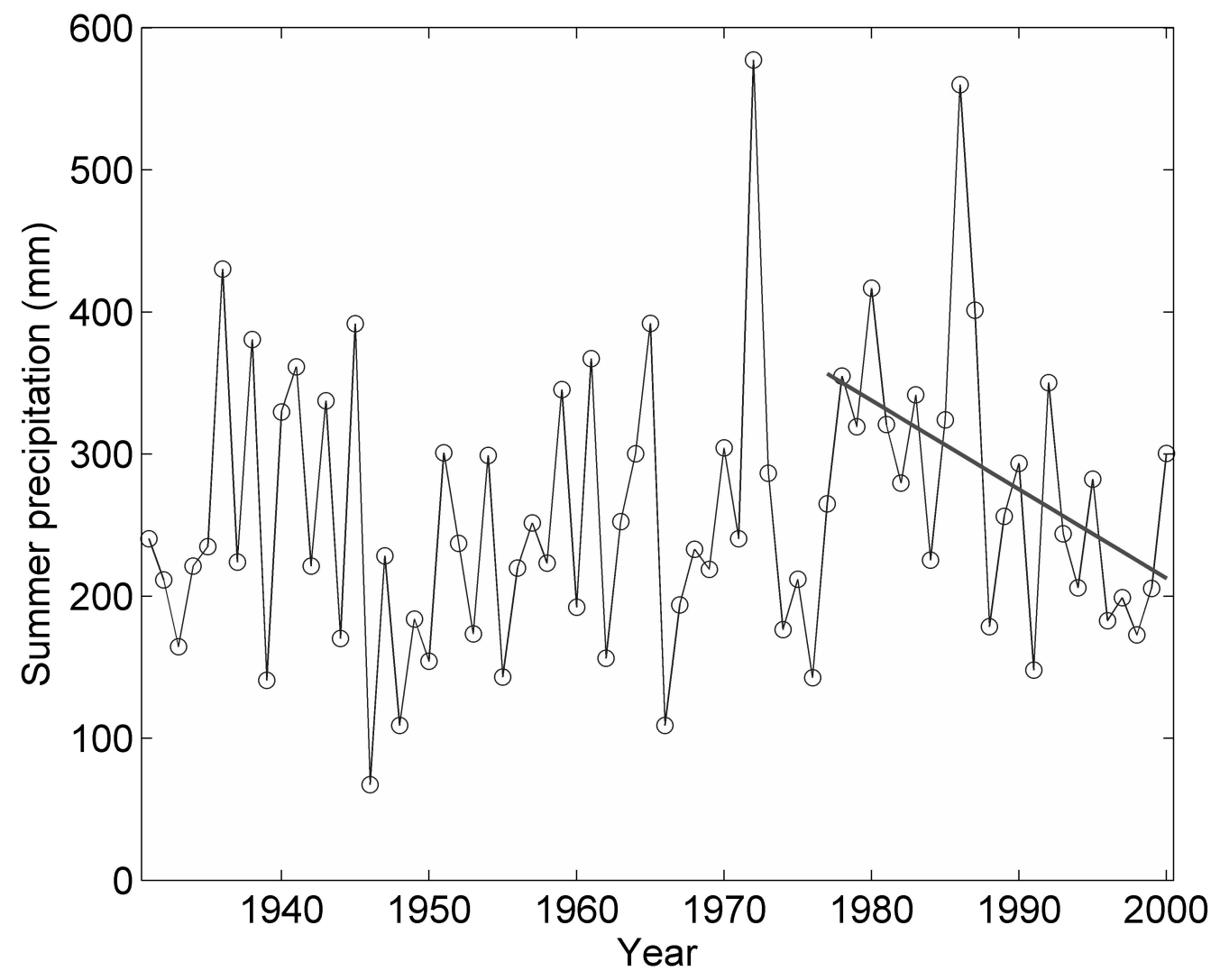

Figure 4: Summer precipitations total for the rainfall gage 119029 at Waukegan. The grey line is the Sen-Theil (Theil, 1950; Sen, 1968) estimate of the linear trend. 

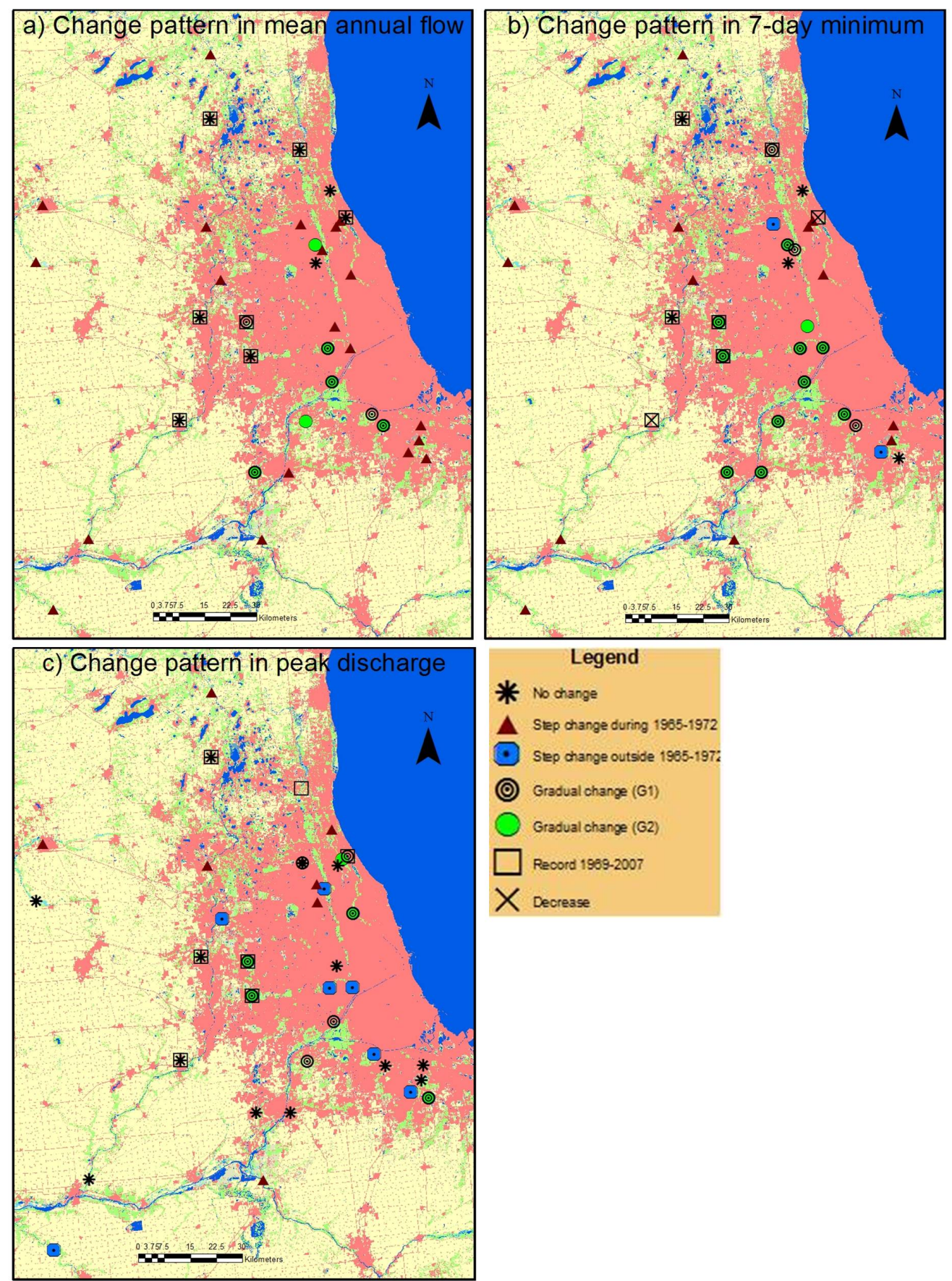

Figure 5: Spatial patterns of change in and around the Greater Chicago Area for $a$ ) mean annual flow, b) 7-day minimum flow and $c$ ) annual daily maximum flow. 

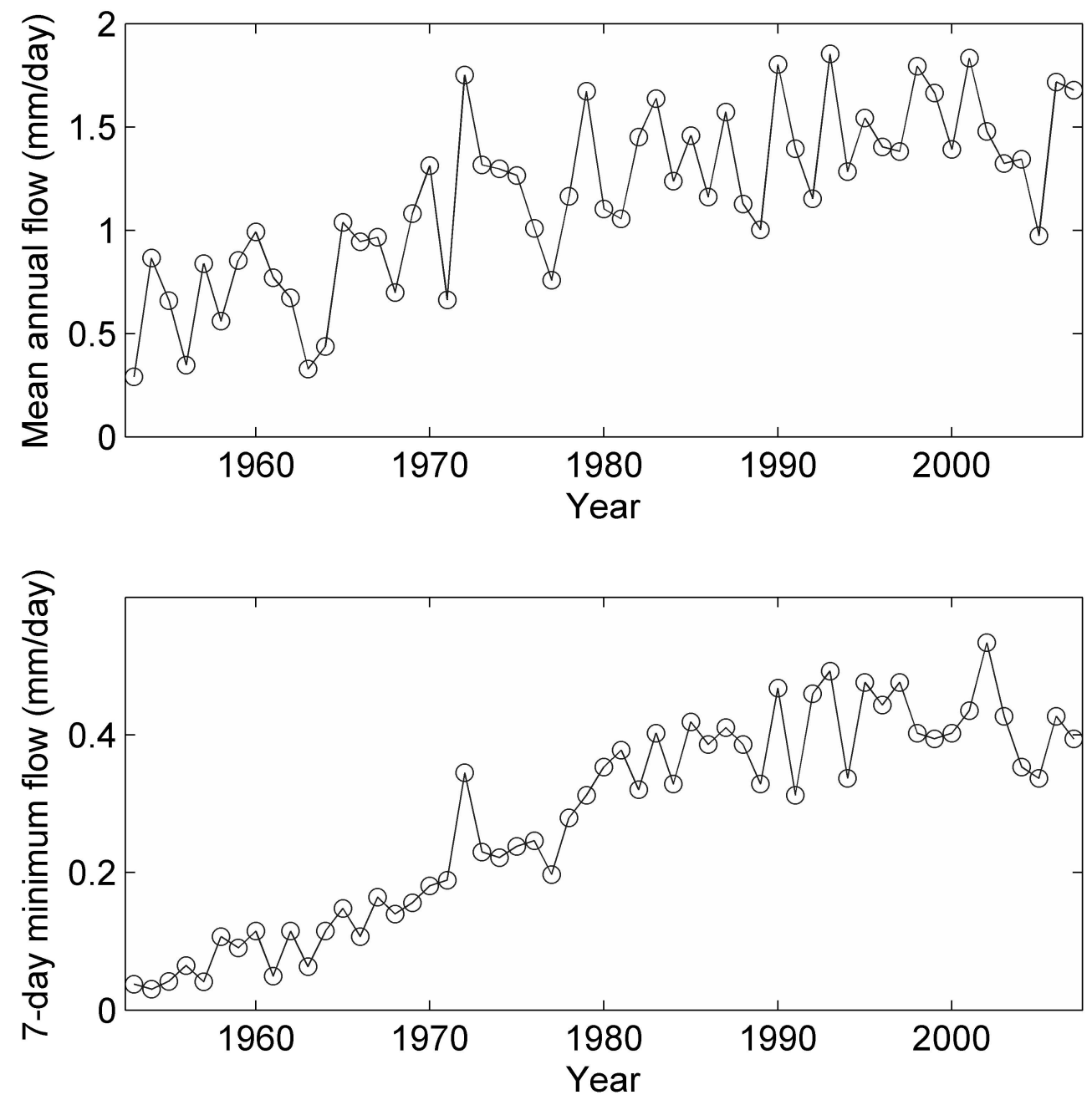

Figure 6: Mean annual flow (above) and 7-day minimum flow (below) for Salt Creek at the 05531500 gage. 

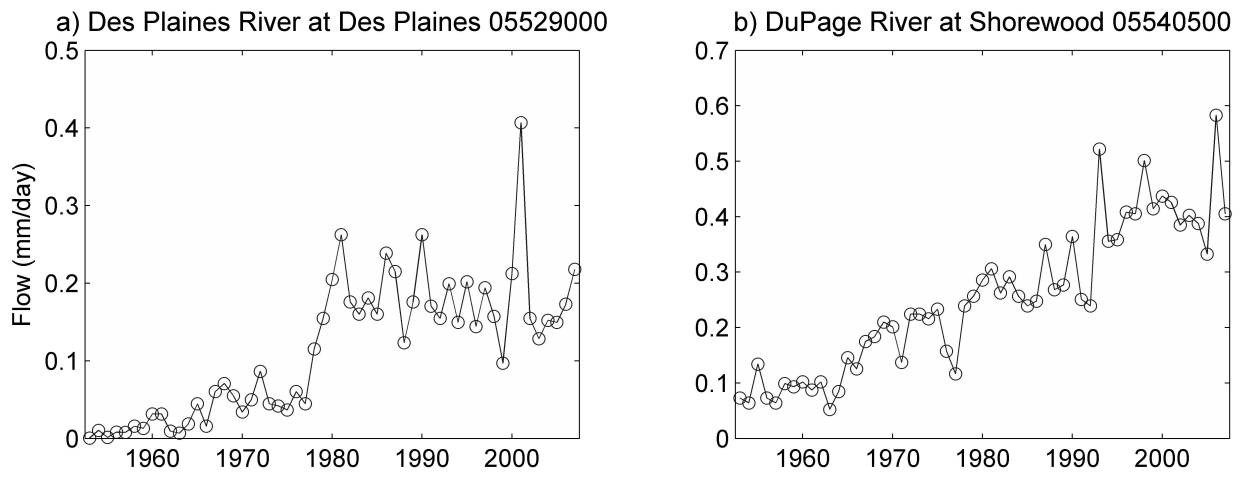

c) Skokie River at Lake Forest 05535000

d) Tinley Creek at Palos Park 05530000
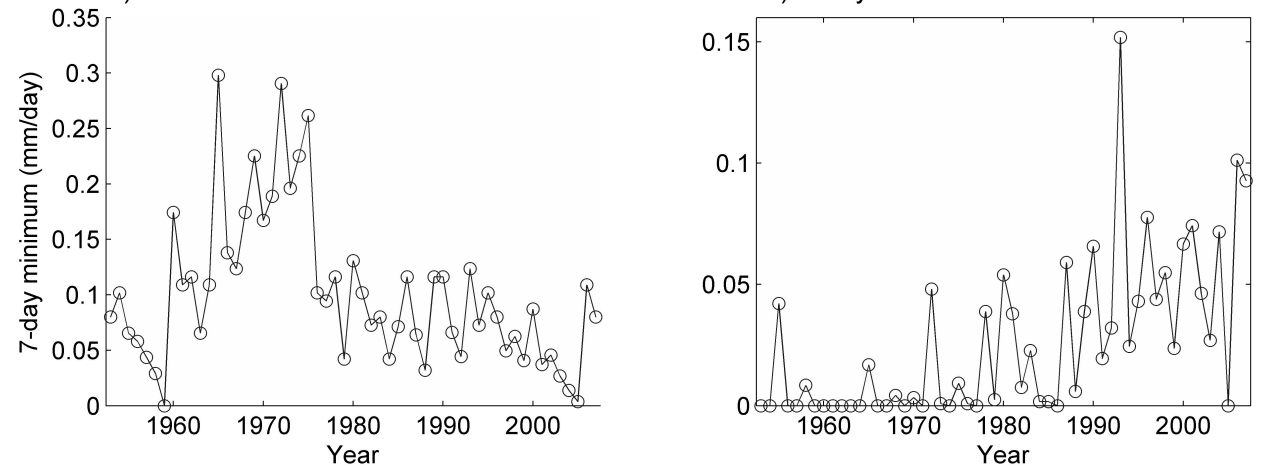

Figure 7: 1953-2007 time series of the 7-day minimum flows at four urban gages. $(a)$ and $(b)$ are the outlets of the two largest urban watersheds while $(c)$ and $(d)$ correspond to small urban watersheds. 


\section{a) POT1}

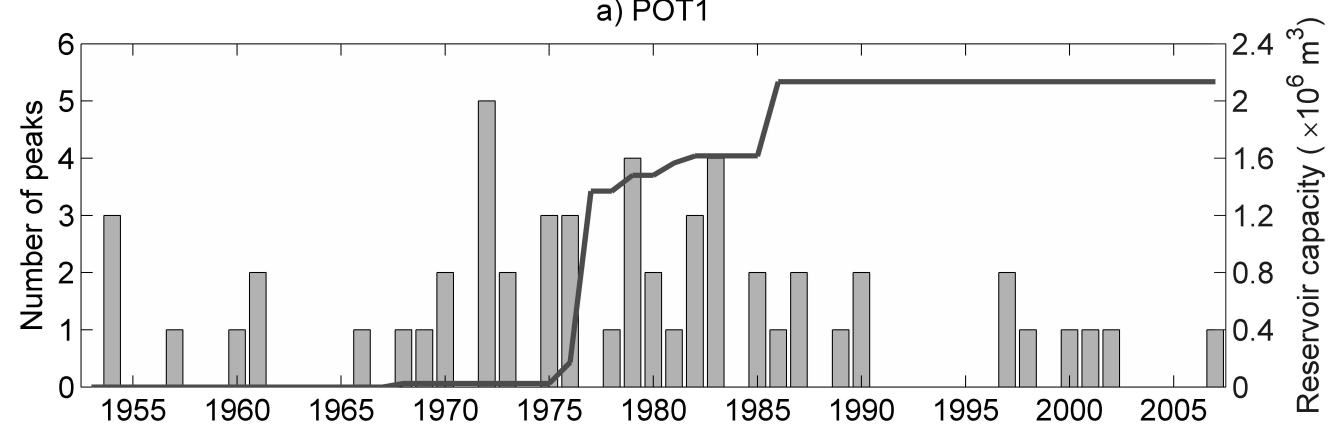

b) $\mathrm{POT} 2$

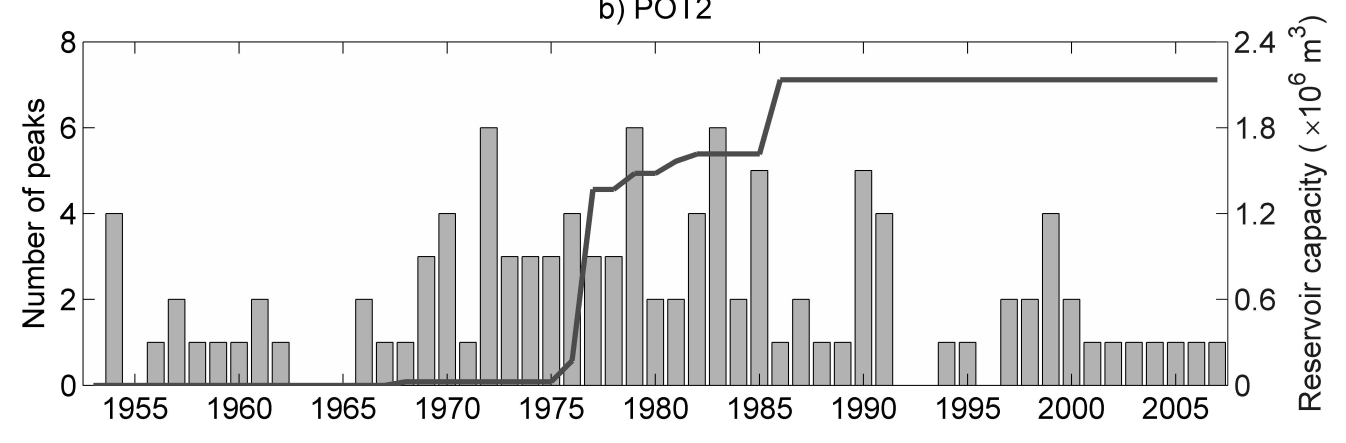

c) РОТ3

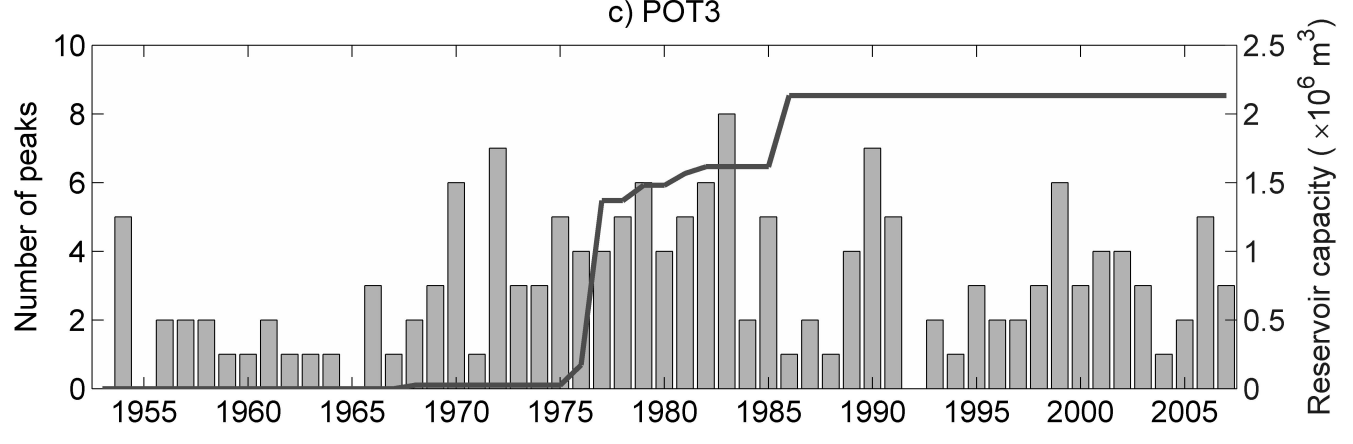

Figure 8: Construction of storm retention reservoirs and peak flow occurrence in the Addison Creek basin (upstream of gage 05532000). 


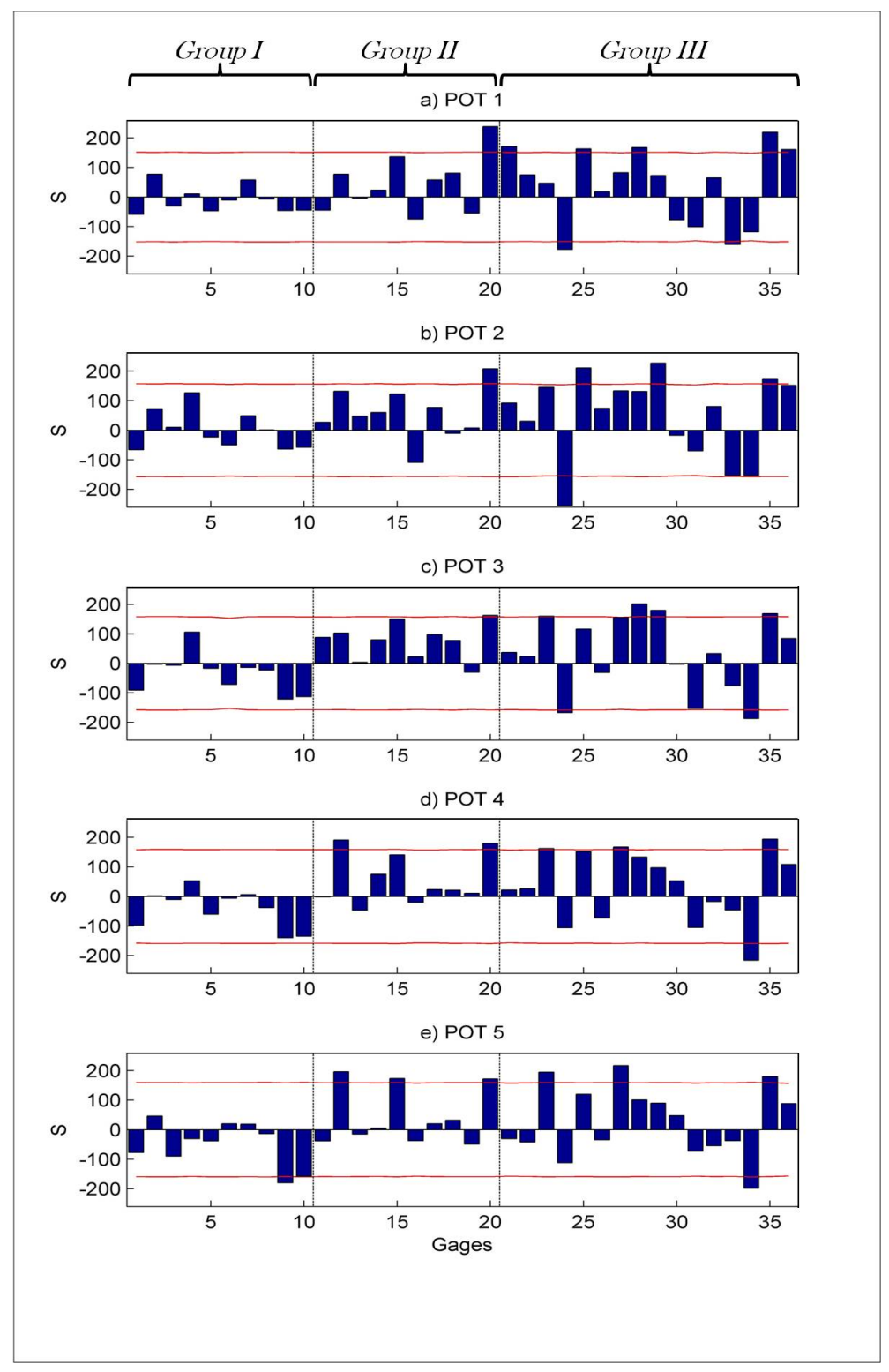

Figure 9: Mann-Kendall statistics $S$ for all the gages (numbered as in Table 3). The red lines represent statistical significance at an individual gage at the $5 \%$ significance level; the dotted black lines delimit the three groups of gages: agricultural, large urban and small urban. 